\title{
THE INFLUENCE OF REDOX STATE ON MICA CRYSTALLIZATION IN LEUCOGRANITIC AND PEGMATITIC LIQUIDS
}

\author{
Michel PICHAVANT ${ }^{\S}$ and ARnaUd VILLAROS \\ Universite' d'Orleans,' ISTO, UMR 7327, 45071 Orleans,' France CNRS/INSU, ISTO, UMR 7327, 45071 Orleans,' France \\ BRGM, ISTO, UMR 7327, BP 36009, 45060 Orleans,' France
}

SARAH DEVEAUD

BRGM, Ressources Minerales,' BP 36009, 45060 Orleans,' France Universite' d'Orleans,' ISTO, UMR 7327, 45071

Orleans,' France CNRS/INSU, ISTO, UMR 7327, 45071 Orleans,' France BRGM, ISTO, UMR 7327, BP 36009, 45060

Orleans,' France

BRuno SCAILLET AND MoHAmed LAHLAFI

Universite' d'Orleans,' ISTO, UMR 7327, 45071 Orleans,' France CNRS/INSU, ISTO, UMR 7327, 45071 Orleans,' France BRGM, ISTO, UMR 7327, BP 36009, 45060 Orleans,' France

\begin{abstract}
Experiments have been performed both on a peraluminous leucogranitic (DK89) and a F-, Li-, P-rich pegmatitic (B2) melt to constrain the stability of micas in evolved crustal silicic magmas and refine mica-melt partition coefficients for $\mathrm{F}$, Li, and $\mathrm{Be}$. The experiments were conducted in parallel in two $\mathrm{f} \mathrm{O}_{2}$ ranges, "oxidizing", (NNO p1 to p3) and "reducing" (NNO -1.6 to -1.4$)$. One two-stage reducing-oxidizing experiment was conducted in a vessel fitted with a $\mathrm{H}_{2}$-permeable Shaw-type membrane. The approach toward equilibrium was tested by imposing long experimental durations and combining mica crystallization experiments with mica dissolution experiments using mica seeds. Experimental micas and melts were analyzed for major elements by electron microprobe and for light elements by nuclear microprobe. At $3 \mathrm{kbar}, 620$ 8C, and under oxidizing conditions, B2 crystallized only muscovite, the biotite seeds reacting to form a new mica intermediate between phengite and Li-rich phengite. Under reducing conditions, biotite (siderophyllite composition) appeared as the stable mica. The two-stage experiment yielded a composite mica assemblage with siderophyllite cores mantled by muscovite rims. At 3.5-3.8 kbar, 720 8C, and under oxidizing conditions, DK89 crystallized only aluminous biotite and muscovite seeds reacted to form biotite-bearing assemblages; muscovite appeared together with biotite at 700 $8 \mathrm{C}$. Under reducing conditions, Al-rich biotite is also the stable mica at 720 8C. Partition coefficients show that $\mathrm{F}$ and $\mathrm{Li}$ are preferentially incorporated in biotite rather than in muscovite, the opposite as for Be. Biotite fractionation buffers the $\mathrm{F}$ and increases the $\mathrm{Li}$ and $\mathrm{Be}$ contents of the residual melt. Muscovite increases the $\mathrm{Li}$ content of the melt and has little influence on $\mathrm{F}$ and $\mathrm{Be}$ concentrations. Our experiments reproduce mica assemblages and compositions typical of Variscan pegmatites and leucogranites, yet very Li-rich micas (e.g., lepidolites) were not obtained. The results stress the differential influence of $\mathrm{f}_{2}$ on mica stability in moderately and highly fractionated crustal melts. Mica crystallization in leucogranites does not appear to be strongly dependent on $\mathrm{f}$ $\mathrm{O}_{2}$. In contrast, a very strong influence of $\mathrm{f}_{2}$ on stable mica assemblages is demonstrated for the pegmatitic melt. The reducing experiments emphasize the existence of a stability field for biotite in melts poor in $\mathrm{Fe}, \mathrm{Mg}$, and $\mathrm{Ti}$. If $\mathrm{f} \mathrm{O}_{2}$ is reducing, biotite must crystallize in moderately to highly evolved peraluminous crustal melts. In contrast, the crystallization of muscovite as the sole mica in evolved crustal melts constitutes an indicator of oxidizing $\mathrm{f}_{2}$. Such an oxidizing evolution that deviates from classical buffered T$\log \mathrm{O}_{2}$ trajectories is the consequence of a mechanism of magma "self-oxidation" that is proposed to result from dissociation of $\mathrm{H}_{2} \mathrm{O}$ in the melt.
\end{abstract}

Keywords: experiments, micas, leucogranite, pegmatite, redox state.

$\S$ Corresponding author email address: pichavan@ cnrs-orleans.fr 
Micas are key mineralogical indicators of the crystallization of silicic rocks. "Two-mica granite" and "lepidolite pegmatite" are examples of widely used definitions that illustrate the importance of micas for the nomenclature of silicic rocks. Indeed, the nature and composition of micas reflect the conditions of crystallization of silicic magmas. The most common igneous mica, biotite, occurs in a variety of silicic to intermediate rocks and is stable for a large range of redox states and melt $\mathrm{H}_{2} \mathrm{O}$ concentrations (e.g., Dodge et al. 1969, Czamanske \& Wones 1973, Neiva 1976). The composition of igneous biotite correlates with magma type and geodynamic setting (Nachit et al. 1985, AbdelRahman 1994). Muscovite crystallization is restricted to peraluminous felsic melts (Miller et al. 1981, Monier et al. 1984, Pichavant et al. 1988, Scaillet et al. 1990, 1995). It is also a marker of the late-magmatic evolution of granitic plutons (Miller et al. 1981, Leroy \& Cathelineau 1982, Nabelek et al. 1992, Speer \& Becker 1992). Less common micas such as zinnwaldite, polylithionite, and lepidolite are typical of highly evolved, Li-, F-rich silicic and pegmatitic rocks (e.g., Monier \& Robert 1986, Congdon \& Nash 1991, Breiter et al. 1997, Raimbault

\section{8, Cerny' et al. 2005, Costi et al. 2009).}

The interest in micas as mineralogical indicators stems from their high structural and chemical flexibility. Micas constitute repositories for major, minor, and trace elements that do not enter into quartz and feldspars, the most abundant mineral phases to crystallize in silicic magmas. In addition to "excess" $\mathrm{Al}_{2} \mathrm{O}_{3}$ and ferromagnesian oxides ("AFM" compo-nents), micas may concentrate a number of minor and trace elements. Some of these elements (F, Li, Be, Cs, Sn, other metals) are now considered as critical, being actively searched for in target rocks such as pegmatites and silicic volcanic rocks (Hofstra et al. 2013, Neiva 2013). To better evaluate the exploration potential of evolved silicic rocks for these elements, conditions of crystallization of micas need to be established, and partition coefficients between micas and melt deter-mined for $\mathrm{F}, \mathrm{Li}$, and other rare elements (Icenhower \& London 1995, Evensen \& London 2002). This forms the objectives of this paper, which reports the results of mica crystallization experiments in leucogranitic and pegmatitic melts. The data enable us to decipher the influence of compositional factors $(\mathrm{F}, \mathrm{Li}, \mathrm{Be}$ enrichment) and especially redox state on the stability and composition of micas. New data on the partition-ing of F, $\mathrm{Li}$, and $\mathrm{Be}$ between mica and melt are presented and the implications for rare-element concentrations in silicic magmas are discussed.
Although silicic compositions have been subjected to numerous experimental studies, most have been performed in relatively simple systems such as the haplogranite system (Johannes \& Holtz 1996). More complex systems where micas (either muscovite or biotite) appear as crystallizing phases have not been systematically investigated. Thus, our knowledge of the stability of mica phases in silicic melts is fragmentary, coming mainly from results from specific, mostly natural, compositions (e.g., Maaløe \& Wyllie 1975, Clemens \& Wall 1981, Naney 1983, Clemens et al. 1986, Scaillet et al. 1995, Dall'Agnol et al. 1999). Another serious limitation is the lack of precise $\mathrm{f}_{2}$ control in many of the early studies.

The stability of micas in silicic peraluminous compositions such as leucogranites was studied by Huang \& Wyllie $(1973,1981)$, mostly above $10 \mathrm{kbar}$, and by Scaillet et al. (1995) at 4 kbar. In the latter study, conditions of biotite and muscovite crystalliza-tion were determined for two leucogranitic melts under moderately reducing conditions (average $\mathrm{f}_{2}$ of $\mathrm{NNO}-1.3$, corresponding to the $\mathrm{f}_{2}$ of the $\mathrm{Ni}-\mathrm{NiO}$ buffer $-1.3 \mathrm{log}$ units). In experiments involving a more F-rich (1.15 wt.\% F) peraluminous fluorite granite (Weidner

\& Martin 1987), muscovite occurred as the only mica phase. In contrast, only biotite appeared in the crystallization sequence of a less peraluminous topaz rhyolite melt ( $1.2 \mathrm{wt} . \% \mathrm{~F})$ between $\mathrm{NNO}-0.8$ and $\mathrm{NNO}$ p0.3 (Webster et al. 1987). Lukkari \& Holtz (2007) crystallized biotite as the sole mica phase in a F-rich (1.13 wt.\% F) topaz granite melt at $\mathrm{NNO}$, muscovite joining biotite when the $\mathrm{F}$ content of the melt was increased to $2.12 \mathrm{wt} . \%$. Melts simultaneously enriched in several fluxing components, and therefore approaching the composition of natural pegmatitic melts, were investigated by Pichavant et al. (1987a) and London et al. (1989), with the synthetic compo-sition of Veksler \& Thomas (2002) lacking critical mica-forming elements such as $\mathrm{Fe}, \mathrm{Mg}$, and $\mathrm{Ti}$. In experiments on the Beauvoir $\mathrm{F}-$, Li-, and P-rich granite, a mica phase was identified in only one crystallization charge (Pichavant et al. 1987a). Zinn-waldite, progressively evolving toward $\mathrm{Li}-$, $\mathrm{Fe}-$ bearing muscovite or lepidolite, was observed in dynamic crystallization experiments using the F-, B-, Li-, P-rich Macusani glass (London et al. 1989).

This overview stresses the lack of information on the crystallization of micas in pegmatitic melts. Compositions of micas crystallized from melts simultaneously enriched in several fluxing components either have not been determined (Pichavant et al.

1987a) or are not known in detail (London et al. 1989). In addition, $\mathrm{f}_{2}$ conditions were not precisely defined 
TABLE 1. STARTING MATERIALS

\begin{tabular}{|c|c|c|c|c|c|c|c|c|}
\hline \multirow{2}{*}{$\begin{array}{l}\text { Sample } \\
\text { Analysis }\end{array}$} & \multicolumn{3}{|c|}{ DK89 } & \multicolumn{3}{|c|}{ B2 } & \multicolumn{2}{|c|}{ DK89 } \\
\hline & whole-rock $\varepsilon$ & 8 glass* & glass $^{* *}$ & whole-rock8 & glass* & glass** & muscovite§ & biotite $\S$ \\
\hline $\mathrm{SiO}_{2}$ (wt.\%) & 73.04 & 73.7 & 73.2 & 71.62 & 73.1 & 72.2 & 46.2 & 34.6 \\
\hline $\mathrm{TiO}_{2}$ & 0.13 & 0.08 & 0.14 & 0.02 & 0.01 & 0.05 & 0.74 & 2.55 \\
\hline $\begin{array}{l}\mathrm{Al}_{2} \mathrm{O}_{3} \\
\mathrm{Fe}_{2} \mathrm{O}_{3}\end{array}$ & $\begin{array}{r}15.32 \\
0.17\end{array}$ & $\begin{array}{l}15.3 \\
\text { nd }\end{array}$ & $\begin{array}{l}15.2 \\
\text { nd }\end{array}$ & $\begin{array}{r}15.79 \\
0.04\end{array}$ & $\begin{array}{l}16.1 \\
\text { nd }\end{array}$ & $\begin{array}{l}16.1 \\
\text { nd }\end{array}$ & $\begin{array}{r}34.1 \\
\text { nd }\end{array}$ & $\begin{array}{r}18.7 \\
\text { nd }\end{array}$ \\
\hline $\mathrm{FeO}$ & 0.74 & $0.81^{1}$ & $0.79^{1}$ & 0.47 & $0.64^{1}$ & $0.45^{1}$ & $1.71^{1}$ & $23.3^{1}$ \\
\hline $\mathrm{MnO}$ & 0.01 & 0.03 & 0.02 & 0.10 & 0.09 & 0.06 & 0.02 & 0.27 \\
\hline $\mathrm{MgO}$ & 0.20 & 0.19 & 0.20 & 0.01 & 0.04 & 0.00 & 0.69 & 4.68 \\
\hline $\mathrm{CaO}$ & 0.85 & 0.93 & 0.91 & 0.19 & 0.33 & 0.33 & nd & nd \\
\hline $\mathrm{Na}_{2} \mathrm{O}$ & 3.85 & 3.88 & 3.80 & 4.52 & 4.28 & 4.69 & 0.63 & 0.05 \\
\hline $\mathrm{K}_{2} \mathrm{O}$ & 4.96 & 4.96 & 4.70 & 3.84 & 3.77 & 3.95 & 10.4 & 9.19 \\
\hline $\mathrm{P}_{2} \mathrm{O}_{5}$ & 0.14 & 0.16 & 0.15 & 0.95 & 0.87 & 1.14 & nd & nd \\
\hline $\mathrm{CO}_{2}$ & 0.05 & nd & nd & 0.03 & nd & nd & nd & nd \\
\hline $\mathrm{H}_{2} \mathrm{O}_{\mathrm{t}}$ & 0.65 & nd & nd & 0.23 & nd & nd & nd & nd \\
\hline $\mathrm{F}$ & 0.09 & $0.00^{2}$ & $1.63^{2}$ & 1.77 & $1.23^{2}$ & $1.80^{2}$ & $0.41^{2}$ & $0.89^{2}$ \\
\hline Total & 100.20 & 100.0 & 100.7 & 98.81 & 100.5 & 100.7 & 95.0 & 94.2 \\
\hline $\begin{array}{l}\mathrm{F}^{1 / 40} \\
\text { Total }\end{array}$ & $\begin{array}{r}0.04 \\
100.16\end{array}$ & $\begin{array}{r}0.00 \\
100.0\end{array}$ & $\begin{array}{r}0.67 \\
100.0\end{array}$ & $\begin{array}{r}0.74 \\
99.55\end{array}$ & $\begin{array}{r}0.51 \\
100.0\end{array}$ & $\begin{array}{r}0.73 \\
100.0\end{array}$ & $\begin{array}{c}0.17 \\
94.8\end{array}$ & $\begin{array}{l}0.37 \\
93.8\end{array}$ \\
\hline Li (ppm) & 163 & $137^{3}-176^{4}$ & $6085^{3}-6937^{4}$ & 3660 & $2286^{3}-2320^{4}$ & $2400^{3}-2661^{4}$ & $367^{4}$ & $951^{4}$ \\
\hline $\mathrm{Be}$ & 14 & $28^{3}-25^{4}$ & $3490^{3}-3858^{4}$ & 35 & $50^{3}-63^{4}$ & $3600^{3}-3858^{4}$ & $49^{4}$ & $38^{4}$ \\
\hline
\end{tabular}

8Whole-rock data: DK89 from Scaillet et al. (1995), B2 from Pichavant et al. (1987a) with Li and Be from Raimbault \& Azencott (1987). * Glass prepared by fusing the whole-rock powder (see text for details); ${ }^{* *}$ glass prepared by fusing

the whole-rock powder and adding $\mathrm{Li}, \mathrm{Be}$, and $\mathrm{F}$ (see text for details). Glass major element data are averages of six electron microprobe spots for each sample, normalized to $100 \%$. $\S$ Muscovite and biotite seeds analyzed by electron microprobe (averages of eight spots).

1 total $\mathrm{Fe}$ as $\mathrm{FeO}$.

2 electron microprobe data.

3 ICP and atomic absorption data.

4 nuclear microprobe data.

in these previous studies. The presence of Al-, Tibearing hematite in the experiments of Pichavant et al. (1987a) suggests that oxidizing redox conditions, tentatively estimated at NNO p3, prevailed. London et al. (1989) observed no crystallization of Fe oxide, the only Fe-bearing phase being zinnwaldite, and considered that $\mathrm{f}_{2}$ was slightly, $\mathrm{NNO}$ in their experiments. Data for mica stability and compositions under precisely constrained redox conditions exist, but for less fractionated melts (Scaillet et al. 1995, Lukkari \& Holtz 2007).

On this basis, two starting compositions were selected for this study, the biotite-muscovite leucogranite from Manaslu (DK89, Scaillet et al. 1995) and the lepidolite-albite granite from Beauvoir (B2, Pichavant et al. 1987a). DK89 is relatively F- and Lipoor whereas $\mathrm{B} 2$ is strongly enriched in $\mathrm{F}, \mathrm{Li}$, and also $P$ (Table 1), thus offering the possibility of testing the influence of chemical fractionation on the stability of mica. Conditions of biotite and muscovite crystallization are well defined for DK89 under moderately reducing conditions (Scaillet et al. 1995) and, although less precisely so, for B2 under oxidizing conditions (Pichavant et al. 1987a), thus providing a basis for further experiments. To assess the influence of $\mathrm{f}_{2}$ on the stability and composition of micas, experiments in this study were conducted in parallel in two $\mathrm{f}_{2}$ ranges, thereafter designated as "oxidizing", (NNO p1 to p3) and "reducing" (NNO -1.6 to -1.4).

\section{EXPERIMENTAl Methods}

Starting materials

The two rocks were ground in an agate mortar to $\sim 20$ $1 \mathrm{~m}$ and then fused in air at $14008 \mathrm{C}$ and $1 \mathrm{~atm}$ in a $\mathrm{Pt}$ tube. For each sample, two cycles of melting of 3 hours each (with grinding in between) were performed, yielding homogeneous nominally dry starting glasses. Additional glasses enriched in $\mathrm{F}, \mathrm{Li}$, and $\mathrm{Be}$ were prepared to help with the determination of mica-melt partition coefficients. This was done by adding $\mathrm{LiF}$ and a $\mathrm{Be}\left(\mathrm{NO}_{3}\right)_{2}$ solution to glasses prepared from the 
rocks. The resulting mixtures were then crushed and dried at $3008 \mathrm{C}$ before being submitted to another cycle of melting at $14008 \mathrm{C}$ and 1 atm for 3 hours. Compositions of starting glasses, both non-enriched and enriched, are given in Table 1. Glasses were crushed to $\sim 20 \mathrm{~lm}$ and permanently stored in an oven.

Most experiments used glasses directly as starting materials and were thus of the crystallization type. In some others, muscovite and biotite seeds (either muscovite alone or a 50:50 mixture of the two micas) were added to the starting glass to test the approach of equilibrium between mica and melt by dissolution, in addition to by crystallization as in the other experiments. These mica seeds were natural biotite and muscovite crystals separated from the Manaslu leucogranite and sieved to a grain size of around 250 $\operatorname{lm}$ (Table 1). The glass and the seeds were pre-mixed before being loaded in the experimental capsule.

\section{Capsules and experimental charges}

All experiments used $\mathrm{Au}$ capsules as containers (inner diameter: $2.5 \mathrm{~mm}$, length: $20 \mathrm{~mm}$, wall thickness: $0.2 \mathrm{~mm}$ ). Except for a few charges, detailed below, all experiments were performed under $\mathrm{H}_{2} \mathrm{O}$ saturated conditions. Typical charges thus consisted of about $50 \mathrm{mg}$ of glass (or glass plus seeds) and about 5 $\mathrm{mg}$ of doubly distilled demineralized water, to keep the proportion of $\mathrm{H}_{2} \mathrm{O}$ at $\sim 10 \mathrm{wt} . \%$ of the total charge.

A few DK89 oxidizing $7008 \mathrm{C}$ charges were prepared under $\mathrm{H}_{2} \mathrm{O}$-undersaturated conditions to test muscovite crystallization at this temperature (see Scaillet et al. 1995, their Fig. 3a). To do so, $\mathrm{H}_{2} \mathrm{O}-\mathrm{CO}_{2}$ fluid mixtures were generated to reduce $\mathrm{aH}_{2} \mathrm{O}$, with silver oxalate as the source of $\mathrm{CO}_{2}$. Three initial fluid compositions [ $\mathrm{XH}_{2} \mathrm{O}$ in. $1 / 4$ molar $\mathrm{H}_{2} \mathrm{O} /\left(\mathrm{H}_{2} \mathrm{O} \mathrm{p} \mathrm{CO} 2\right)$ ] were investigated: $0.9,0.8$, and 0.7 , while keeping the proportion of fluid components at $\sim 10 \mathrm{wt} . \%$, as in the $\mathrm{H}_{2} \mathrm{O}$-saturated experiments.

Beauvoir (B2) experiments: equipment and control of $\mathrm{fO}_{2}$

Previous experiments on the B2 (Beauvoir) composition have defined a favorable pressure-temperature window for mica crystallization, between 600 and $6508 \mathrm{C}$ at 3 kbar (Pichavant et al. 1987a, their Fig. 2). Accordingly, most of the new B2 experiments were performed at $6208 \mathrm{C}$, and only a few at 700 and $7508 \mathrm{C}$, all for a pressure of $3 \mathrm{kbar}$. All B2 experiments were carried out in horizontal externally heated rapid-quench cold-seal hydrothermal pressure vessels (Pichavant 1987, Schmidt et al. 1995). Total pressures were read with a Bourdon-tube manometer with an uncertainty estimated to be p20 bar. Temperatures were measured continuously with a type-K thermo- couple located in a well drilled at the bottom of the vessel. Temperature readings, calibrated against measurements using an internal thermocouple working under pressure, are accurate to better than $108 \mathrm{C}$. At the end of the experiments, the vessel was tilted vertically and capsules slid from the hot spot to the cold bottom part of the vessel over a few seconds.

Three techniques were employed to control redox conditions in these pressure vessels (Table 2). (1) For the oxidizing experiments, pure Ar was used as the pressurizing gas. In this case, the $\mathrm{f}_{2}$ is imposed intrinsically by the gas and vessel (intrinsic $\mathrm{f}_{2}$ control). $\mathrm{f} \mathrm{H}_{2}$ was measured both at 620 ( $\mathrm{f} \mathrm{H}_{2} \frac{1}{1 / 4} 3-4$ bar) and $7008 \mathrm{C}$ ( $\mathrm{f} \mathrm{H}_{2} 1 / 43$ bar) with NiPd-NiO solid sensors (Taylor et al. 1992). Given that the experimental charges were all $\mathrm{H}_{2} \mathrm{O}$-saturated, these intrinsic f $\mathrm{H}_{2}$ correspond to $\log \mathrm{f}_{2}$ of $\mathrm{NNO} p 0.7-1.1$ and NNO p1.1 respectively at 620 and 700 8C (calculations performed with $\mathrm{K}_{\text {water }}$ from Robie et al. 1979, fH2O8 from Burnham et al. 1969 and the NNO equation of Chou 1987). In the following, a DNNO of p1 will be assumed for all oxidizing B2 charges (Table 2). (2) For the reducing experiments, again pure $\mathrm{Ar}$ was the pressurizing gas, but elevated $\mathrm{f}_{2}$ conditions were imposed on the experimental charges by the double-capsule method of Eugster (1957). A $\mathrm{Co}-\mathrm{CoO}(\mathrm{CCO})$ buffer assemblage was used, yielding a DNNO of around -1.4 for all reducing B2 charges (CCO and NNO calibrations from Chou 1987). The buffer was loaded into a $0.4 \mathrm{~mm}$ wall-thickness external $\mathrm{Au}$ capsule to minimize $\mathrm{H}_{2}$ loss toward the $\mathrm{Ar}$ gas. Persistence of buffer phases and the presence of residual water were checked at the end of the experiments. Our low experimental temperatures ensured the successful implementation of this method (see Scaillet et al. 1992, Schmidt et al. 1995). (3) A two-stage reduction-oxidation experiment was conducted at $6208 \mathrm{C}$ and $3 \mathrm{kbar}$ in a vessel fitted with a $\mathrm{H}_{2}$-permeable Shaw-type membrane (Schmidt et al. 1995). The vessel was first pressurized with an $\mathrm{Ar}-\mathrm{H}_{2}$ mixture to yield a $\mathrm{f}_{2}$ of 55 bar, corresponding to a DNNO of -1.6 for the $\mathrm{H}_{2} \mathrm{O}$-saturated charges, as read and stabilized by the $\mathrm{H}_{2}$ membrane. These reducing conditions were imposed for one week. Second, the $\mathrm{H}_{2}$ membrane and line were evacuated while temperature and pressure were kept constant, and $\mathrm{H}_{2}$ was forced to diffuse out of the vessel and capsule through the membrane. Nearly total exhaustion of the vessel was achieved in a few hours as confirmed by a drop of $\sim 55$ bar in total pressure. The procedure was periodically repeated to drain off any $\mathrm{H}_{2}$ dissolved in the capsule and vessels walls, yielding a $\mathrm{f} \mathrm{H}_{2}$ of $\sim 0.4$ bar inside the vessel (corresponding to a DNNO of p2.7 for the $\mathrm{H}_{2} \mathrm{O}$-saturated charges) which was maintained for another week (Table 2). 
TABLE 2. CONDITIONS AND RESULTS OF THE B2 EXPERIMENTS

\begin{tabular}{|c|c|c|c|c|c|c|c|}
\hline Charge \# & DNNO & $\mathrm{T}(8 \mathrm{C})$ & $\mathrm{P}$ (bar) & $\mathrm{aH}_{2} \mathrm{O}$ & $\begin{array}{l}\text { Duration } \\
\text { (weeks) }\end{array}$ & Phase assemblage & $\mathrm{fO}_{2}$ control \\
\hline \multicolumn{8}{|l|}{ Oxidizing } \\
\hline 2 & p1 & 620 & 3000 & 1 & 6 & L, Qz, PI, Fk, Mu, Ap, Mt & Intrinsic \\
\hline 31 & p1 & 620 & 3000 & 1 & 12 & $\mathrm{~L}, \mathrm{Qz}, \mathrm{PI}, \mathrm{Fk}, \mathrm{Mu}, \mathrm{Ap}, \mathrm{Mt}$ & Intrinsic \\
\hline 4 & p1 & 620 & 3000 & 1 & 12 & $\mathrm{~L}, \mathrm{Qz}, \mathrm{Pl}, \mathrm{Fk}, \mathrm{Mu}, \mathrm{Ap}, \mathrm{Mt}$ & Intrinsic \\
\hline 5 & p1 & 620 & 3000 & 1 & 24 & L, Qz, PI, Fk, Mu, Ap, Mt & Intrinsic \\
\hline $63^{2}$ & p1 & 700 & 3000 & 1 & 1 & L, Ap & Intrinsic \\
\hline $13_{1,3}$ & $\begin{array}{l}\mathrm{p} 1 \\
\mathrm{~b} 1\end{array}$ & $\begin{array}{l}620 \\
620\end{array}$ & $\begin{array}{l}3000 \\
3000\end{array}$ & $\begin{array}{l}1 \\
1\end{array}$ & $\begin{array}{l}24 \\
12\end{array}$ & $\begin{array}{l}\text { L, Qz, PI, Fk, Ap, Ber, Mt } \\
\text { L, Qz, Pl, Fk, Mu, Ap, Mt }\end{array}$ & $\begin{array}{l}\text { Intrinsic } \\
\text { Intrinsic }\end{array}$ \\
\hline $\begin{array}{l}18_{2,3} \\
204\end{array}$ & $\begin{array}{l}\text { p1 } \\
\text { p1 }\end{array}$ & $\begin{array}{l}620 \\
620\end{array}$ & $\begin{array}{l}3000 \\
3000\end{array}$ & $\begin{array}{l}1 \\
1\end{array}$ & $\begin{array}{l}24 \\
12\end{array}$ & $\begin{array}{l}\text { L, Qz, PI, Fk, Mu, Ap, Mt } \\
\text { L, Qz, Pl, Fk, Ap, Ber, Mt }\end{array}$ & $\begin{array}{l}\text { Intrinsic } \\
\text { Intrinsic }\end{array}$ \\
\hline $\begin{array}{l}24 \\
\text { Reducing }\end{array}$ & p1 & 620 & 3000 & 1 & 6 & $\mathrm{~L}, \mathrm{Qz}, \mathrm{Pl}, \mathrm{Fk}, \mathrm{Mu}, \mathrm{Bt}, \mathrm{Ap}, \mathrm{Mt}$ & Intrinsic \\
\hline 38 & -1.4 & 620 & 3000 & 1 & 2 & $\mathrm{~L}, \mathrm{Bt}, \mathrm{Ap}$ & Co-CoO buffe \\
\hline $39^{1}$ & -1.4 & 620 & 3000 & 1 & 1.5 & $\mathrm{~L}, \mathrm{Bt}, \mathrm{Ap}$ & Co-CoO buffe \\
\hline $\begin{array}{l}40^{1} \\
41\end{array}$ & $\begin{array}{l}-1.4 \\
-1.4\end{array}$ & $\begin{array}{l}620 \\
700\end{array}$ & $\begin{array}{l}3000 \\
3000\end{array}$ & $\begin{array}{l}1 \\
1\end{array}$ & $\begin{array}{l}2 \\
1\end{array}$ & $\begin{array}{l}\text { L, Bt, Ap } \\
\text { L, Ap }\end{array}$ & $\begin{array}{l}\text { Co-CoO buffer } \\
\text { Co-CoO buffer }\end{array}$ \\
\hline $\begin{array}{c}44^{4} \\
\text { Two-stage }\end{array}$ & -1.4 & 620 & 3000 & 1 & 2 & $\mathrm{~L}, \mathrm{Mu}, \mathrm{Bt}, \mathrm{Ap}$ & Co-CoO buffer \\
\hline 77 & $-1.6 \cdot \mathrm{p} 2.7$ & 620 & 3000 & 1 & 3 & $L, Q z, P I, F k, B t, M u, A p, M t$ & $\mathrm{H}_{2}$ membrane \\
\hline \multicolumn{8}{|c|}{$\begin{array}{l}1 \text { includes a preconditioning dwell at superliquidus conditions (see text). } \\
2 \text { performed with the Li-, Be-, and F-enriched starting glass (Table 1). } \\
3 \text { muscovite seeded. } \\
4 \text { muscovite and biotite seeded. }\end{array}$} \\
\hline
\end{tabular}

Manaslu (DK89) experiments: equipment and control of $\mathrm{fO}_{2}$

The new experiments were based on previous work by Scaillet et al. (1995) who found biotite crystallizing below $8008 \mathrm{C}$ and biotite plus muscovite below 700 $8 \mathrm{C}$ for a pressure of $\sim 4000$ bar and $\mathrm{f}_{2} \frac{1 / 4}{} \mathrm{NNO}-1.3$. Two experiments were performed at $7208 \mathrm{C}$ for reducing and oxidizing $\mathrm{f}_{2}$. A third experiment was aimed at testing the co-crystallization of biotite and muscovite at $7008 \mathrm{C}$ under oxidizing conditions (Scaillet et al. 1995, Pichavant et al. 1996).

The three DK89 experiments (Table 3) were performed in a large-volume internally heated pressure vessel fitted with an $\mathrm{H}_{2}$-permeable Shaw-type mem-brane and arranged vertically (Scaillet et al. 1992). $\mathrm{H}_{2}$ and $\mathrm{Ar}$ gases, loaded sequentially at room temperature, were used to pressurize the vessel. Redox conditions were controlled by varying the initial pressure of $\mathrm{H}_{2}$ gas, and experimental $\mathrm{f}_{2}$ were continuously read with the $\mathrm{H}_{2}$ membrane. For the three experiments, the measured $\mathrm{fH}_{2}$ (67, 0.85, 0.4 bar) correspond to DNNO of $-1.5, \mathrm{p} 2.3$, and 2.7 respectively for the $\mathrm{H}_{2} \mathrm{O}$ - saturated charges. For the $\mathrm{H}_{2} \mathrm{O}$-undersaturated charges, DNNO is estimated to be between p2.7 and p2.5 (Table 3). Total pressure was permanently recorded and is known to better than p20 bar. Temperature was continuously measured by three thermocouples with an uncertainty of p5 8C. At the end of the experiment, the power to the furnace was switched off and the temperature dropped by about $3008 \mathrm{C}$ during the first 4 minutes.

Experimental durations and time-temperature paths

Because of the need to obtain mica phases large enough for major element but also $\mathrm{Li}, \mathrm{Be}$, and $\mathrm{F}$ analyses, specific experimental methods were imple-mented. Long experimental durations were considered, especially for the low-temperature B2 experiments. At $6208 \mathrm{C}$ under oxidizing conditions, durations were a minimum of six weeks, more rarely 12 weeks, and several experiments lasted up to 24 weeks (Table 2). Another approach was to adapt the experimental time-temperature path so as to promote crystal growth. Instead of directly approaching experimental temper- 
TABLE 3. CONDITIONS AND RESULTS OF THE DK89 EXPERIMENTS

\begin{tabular}{|c|c|c|c|c|c|c|c|}
\hline Charge \# & DNNO & $\mathrm{T}(8 \mathrm{C})$ & $\mathrm{P}$ (bar) & $\mathrm{aH}_{2} \mathrm{O}$ & $\begin{array}{l}\text { Duration } \\
\text { (weeks) }\end{array}$ & Phase assemblage & $\mathrm{fO}_{2}$ control \\
\hline \multicolumn{8}{|l|}{ Oxidizing } \\
\hline 271 & p2.3 & 720 & 3750 & 1 & 2 & $\mathrm{~L}, \mathrm{Bt}$ & $\mathrm{H}_{2}$ membrane \\
\hline 322 & p2.3 & 720 & 3750 & 1 & 2 & L, Ber & $\mathrm{H}_{2}$ membrane \\
\hline $\begin{array}{l}33 \\
28\end{array}$ & $\begin{array}{l}\text { p2.3 } \\
\text { p2.7 }\end{array}$ & $\begin{array}{l}720 \\
700\end{array}$ & $\begin{array}{l}3750 \\
3550\end{array}$ & $\begin{array}{l}1 \\
1\end{array}$ & $\begin{array}{l}2 \\
2\end{array}$ & $\begin{array}{l}\text { L, Bt, Mu } \\
\text { L, Fk, Bt }\end{array}$ & $\begin{array}{l}\mathrm{H}_{2} \text { membrane } \\
\mathrm{H}_{2} \text { membrane }\end{array}$ \\
\hline 29 & $\sim$ p2.6 & 700 & 3550 & $\sim 0.9$ & 2 & $\mathrm{~L}, \mathrm{Fk}, \mathrm{Bt}$ & $\mathrm{H}_{2}$ membrane \\
\hline 30 & $\sim \mathrm{p} 2.6$ & 700 & 3550 & $\sim 0.8$ & 2 & L, Qz, Fk, PI, Bt & $\mathrm{H}_{2}$ membrane \\
\hline $\begin{array}{l}31 \\
\text { Reducing }\end{array}$ & $\sim p 2.5$ & 700 & 3550 & $\sim 0.7$ & 2 & $\mathrm{~L}, \mathrm{Qz}, \mathrm{Fk}, \mathrm{Pl}, \mathrm{Bt}, \mathrm{Mu}$ & $\mathrm{H}_{2}$ membrane \\
\hline 46 & -1.5 & 720 & 3600 & 1 & 2 & $\mathrm{~L}, \mathrm{Bt}$ & $\mathrm{H} 2$ membrane \\
\hline $47^{1}$ & -1.5 & 720 & 3600 & 1 & 2 & $\mathrm{~L}$ & H2 membrane \\
\hline $48^{2}$ & -1.5 & 720 & 3600 & 1 & 2 & $\mathrm{~L}, \mathrm{Bt}, \mathrm{Mu}$ & $\mathrm{H}_{2}$ membrane \\
\hline $49_{1,2}$ & -1.5 & 720 & 3600 & 1 & 2 & $\mathrm{~L}, \mathrm{Bt}, \mathrm{Mu}$ & $\mathrm{H}_{2}$ membrane \\
\hline
\end{tabular}

All experiments included a preconditioning dwell at superliquidus conditions (see text).

1 performed with the $\mathrm{Li}-, \mathrm{Be}-$, and F-enriched starting glass.

2 muscovite and biotite seeded.

L: silicate glass, Qz: quartz, PI: plagioclase, Fk: K-feldspar, Mu: muscovite solid solution, Bt: biotite solid solution, Ber: beryl.

ature and pressure starting from room conditions, several B2 and the three DK89 experiments passed through an initial preconditioning dwell of two days either at $7008 \mathrm{C}(\mathrm{B} 2)$ or $8008 \mathrm{C}$ (DK89) to equilibrate the charges above the liquidus. Then, experiments were rapidly (in about $15 \mathrm{~min}$ ) cooled to the different target temperatures to inhibit crystal nucleation, and these final conditions were kept steady until quench. Note that, because of limitations imposed by the equipment, the cooling step was isobaric for the B2 but not quite so for the DK89 experiments (where the pressure dropped from $\sim 4000$ to $3550-3750$ bar, Table $3)$. For the reduction-oxidation B2 experiment (Table 2 ), the reducing stage at $6208 \mathrm{C}$ was preceded by a seven-day preconditioning dwell at $7008 \mathrm{C}$ (total pressure $1 / 4 \quad 3$ kbar, $\mathrm{f} \quad \mathrm{H}_{2} \quad 1 / 4 \quad 55$ bar) before the temperature was lowered to $6208 \mathrm{C}$ (under constant total pressure and $\mathrm{f}_{2}$ ).

\section{Analytical Methods}

Phase identification

Experimental products and solid sensors were observed microscopically, then by X-ray techniques and, for selected charges, by scanning electron microscopy (SEM). The X-ray measurements were performed mostly with a SIEMENS diffractometer (Co Ka radiation, $2 \mathrm{~h} 1 / 46$ to 808 ), more rarely with an INEL instrument. The SEM observations were carried out in backscattered electron mode using a JEOL 6100 microscope (BRGM, Orleans)'.
Major element analysis

Experimental crystalline phases (micas and other phases), glasses, and solid sensors were analyzed with a CAMECA SX 50 electron microprobe at Orleans'. For crystalline phases, the beam was focused to 1-2 $\mathrm{lm}$. Analytical conditions were $15 \mathrm{kV}$ (acceleration voltage), $12 \mathrm{nA}$ (sample current), and $10 \mathrm{sec}$ (counting time) for all elements ( $\mathrm{Si}, \mathrm{Ti}, \mathrm{Al}, \mathrm{Fe}, \mathrm{Mn}, \mathrm{Mg}, \mathrm{Ca}, \mathrm{Na}$, $\mathrm{K}, \mathrm{P}, \mathrm{F})$. Silicate minerals including micas were used as standards (topaz for F) and the data was processed using ZAF and PAP correction procedures. Metallic alloys from sensor phase assemblages were analyzed with higher acceleration voltage $(20 \mathrm{kV})$ and sample currents $(20 \mathrm{nA})$. Glasses were analyzed with a $6 \mathrm{nA}$ sample current and a defocused beam $(10 \mathrm{~lm})$. Alkali correction procedures followed the methodology of Pichavant (1987), a Macusani obsidian glass (Pichavant et al. 1987b) being used as a secondary standard. For the silicate phases, the relative analytical errors are $1 \%\left(\mathrm{SiO}_{2}, \mathrm{Al}_{2} \mathrm{O}_{3}, \mathrm{CaO}\right), 3 \%(\mathrm{FeO}, \mathrm{MgO}$, $\left.\mathrm{TiO}_{2}\right)$, and $5 \%\left(\mathrm{MnO}, \mathrm{Na}_{2} \mathrm{O}, \mathrm{K}_{2} \mathrm{O}, \mathrm{P}_{2} \mathrm{O}_{5}, \mathrm{~F}\right)$. Mole fractions of $\mathrm{Ni}$ and $\mathrm{Pd}$ in alloys are known to p0.01. $\mathrm{Fe}^{2 \mathrm{p}}$ and $\mathrm{Fe}^{3 \mathrm{p}}$ in micas were estimated after Redhammer et al. (1993, 2000) from structural formulae calculated on the basis of electron microprobe analyses.

\section{Light element analysis}

Besides $F$ by electron microprobe, different analytical methods were used for the analysis of $\mathrm{Li}$, 
$\mathrm{Be}$, and $\mathrm{F}$. The starting glasses were analyzed for $\mathrm{Li}$ by atomic absorption and for $\mathrm{Li}$ and $\mathrm{Be}$ by ICP. The different methods yielded comparable results (Table 1).

A nuclear microprobe (LPS, Saclay) was used for the analysis of $\mathrm{Li}, \mathrm{Be}$, and $\mathrm{F}$ in experimental micas and glasses. The facility consists of a single-stage Van De Graaff accelerator and two microbeam lines (Khodja et al. 2001). The $\mathrm{Li}, \mathrm{Be}$, and $\mathrm{F}$ analyses were based on the ${ }^{7} \mathrm{Li}\left(\mathrm{a}, \mathrm{a}^{\prime}\right){ }^{7} \mathrm{Li},{ }^{9} \mathrm{Be}(\mathrm{a}, \mathrm{n}){ }^{12} \mathrm{C}$, and ${ }^{19} \mathrm{~F}\left(\mathrm{a}, \mathrm{a}^{\prime}\right){ }^{19} \mathrm{~F}$ nuclear reactions, respectively. The samples were irradiated with particle beams with energies between 3 and $3.5 \mathrm{MeV}$. Emitted c-rays were quantified with a HP Ge detector. Typical microbeam sizes were 2 and

$20 \mathrm{~lm}$ for micas and glasses respectively. The data were standardized against natural beryl (for $\mathrm{Be}$ ) and amblygonite (for $\mathrm{Li}, \mathrm{F}$ ). Calculated relative uncertain-

ties are variable. For $\mathrm{Li}$, they decrease with the element concentration, from $\sim 20 \%(, 500 \mathrm{ppm})$ to $5 \%$ or less (1000 ppm range). For Be, they are on the order of $\sim 20 \%$ and for $\mathrm{F}$ approximately $10 \%$.

The empirical equations of Tischendorf et al. (1997) were used to estimate the Li contents of micas that were not analyzed. For internal consistency, all

micas (including those analyzed for $\mathrm{Li}$ ) are represented graphically on the $[\mathrm{Mg}-\mathrm{Li}]$ versus [Fetot $p$ $\mathrm{Mn} \mathrm{p} \mathrm{Ti}-\mathrm{Al}^{\mathrm{VI}}$ ] diagram where $\mathrm{Li}$ is estimated empirically (Tischendorf et al. 1997).

\section{RESULTS}

A total of 48 experimental charges, 34 B2 and 14 DK89, were characterized in detail. Below, we focus on the relationships between starting glass compositions, experimental conditions, especially the redox state, and mica types and compositions. Additional information (experiments, textural descriptions of seeds, composition of crystals other than micas) can be found in Lahlafi (1997).

Several lines of evidence indicate that the phase assemblages determined in this study, and the phase compositions (especially micas), correspond to nearequilibrium states. This includes (1) the reproducibility of the experimental results: for charges exposed to the same P-T-DNNO conditions, the phase assemblages are all identical, showing no variation with experi-mental durations and time-temperature trajectories. It is also emphasized that unusually long experiments (some up to six months) have been conducted in this study. (2) The chemical homogeneity of analyzed phases: micas and glasses in a given charge (exception made for the seeded charges) are homogeneous; in charges with the same starting composition submitted to the same P-T-DNNO conditions, the micas have identical compositions. (3) Crystallization and disso- lution experiments yielded identical results concerning mica stability, thus demonstrating reversibility. Yet, in the seeded experiments, phase assemblages and mica composition differ in reaction zones around the seeds and away from them. Chemical zonations were recognized and so no equilibrium at the scale of the entire charge is claimed in those experiments.

Three types of micas (apart from the seeds) were distinguished on a textural basis. These include micas (either muscovite or biotite) directly crystallized from the melt (textural type C), compositions rimming muscovite or biotite seeds (textural type Srim), and newly formed micas crystallizing in reaction zones adjacent to the seeds (textural type Snew).

\section{Beauvoir (B2) experiments}

Under oxidizing conditions, mica was found to crystallize only at $6208 \mathrm{C}$ (Table 2). Experiments at $7008 \mathrm{C}$ (charge \#6) and 750 8C (Lahlafi 1997) were mica-free. Experiments with the $\mathrm{Li}-, \mathrm{Be}-$, and $\mathrm{F}$ enriched B2 glass also did not crystallize mica at 620 8C (charge \#13). Mica-bearing charges contain small amounts of quartz, plagioclase, alkali feldspar, apatite, and magnetite. Beryl occurs in charges starting from the enriched B2 glass, but does not co-crystallize with mica. Mica sizes increase with experimental duration, from , $15 \mathrm{~lm}$ (six weeks) to ,40 $\mathrm{lm}$ (24 weeks). The largest micas (length ,120 $\mathrm{lm}$ ) crystallized in experiment \#4 performed with the preconditioning dwell (Fig. 1a).

Representative compositions of micas are given in Table 4. Type $\mathrm{C}$ micas in charges $2,3,4$, and 5 (same PT-DNNO conditions) all have the same composition. In charge \#17, a muscovite-seeded charge run under the same conditions (Table 2), C micas away from the seeds are identical to $\mathrm{C}$ micas in non-seeded charges. These $\mathrm{C}$ micas are muscovites (Fig. 2) containing elevated $\mathrm{Al}_{2} \mathrm{O}_{3}$ (33.5-34.5 wt.\%), significant amounts of $\mathrm{F}(\sim 1.4 \mathrm{wt} . \%)$, relatively low $\mathrm{FeO}_{\mathrm{t}}\left(2.5-4\right.$ wt.\%), and low $\mathrm{TiO}_{2}, \mathrm{Na}_{2} \mathrm{O}$, and $\mathrm{MgO}$ (Table 4). $\mathrm{X}_{\mathrm{Fe}}$ [at. $\mathrm{Fe}^{2 \mathrm{p}}$

/ $\left(\mathrm{Fe}^{2 \mathrm{p}} \mathrm{p} \mathrm{Mg}\right)$ with $\mathrm{Fe}^{2 \mathrm{p}}$ calculated after Redhammer et al. 1993, 2000] is $\sim 0.8 . \mathrm{Li}$ and Be concentrations range between 800 and $1000 \mathrm{ppm}$ and 30 and 150 ppm, respectively (Table 4).

The muscovite-seeded products were all texturally similar, whether preconditioned at $7008 \mathrm{C}$ for two days (charge \#17) or not (charges \#18, 20, Table 2). Seeds kept their original sizes unchanged. Interfaces with the glass are sharp and breakdown phases are absent, suggesting that the muscovite seeds are stable. Yet the outer zone (the first 30-40 $\mathrm{lm}$ ) of the seeds (textural type Srim) shows a progressive enrichment in $\mathrm{Fe}, \mathrm{F}, \mathrm{Li}$, and Be compared to the core, which retains the composition of the starting crystal (Tables 1, 4). In 

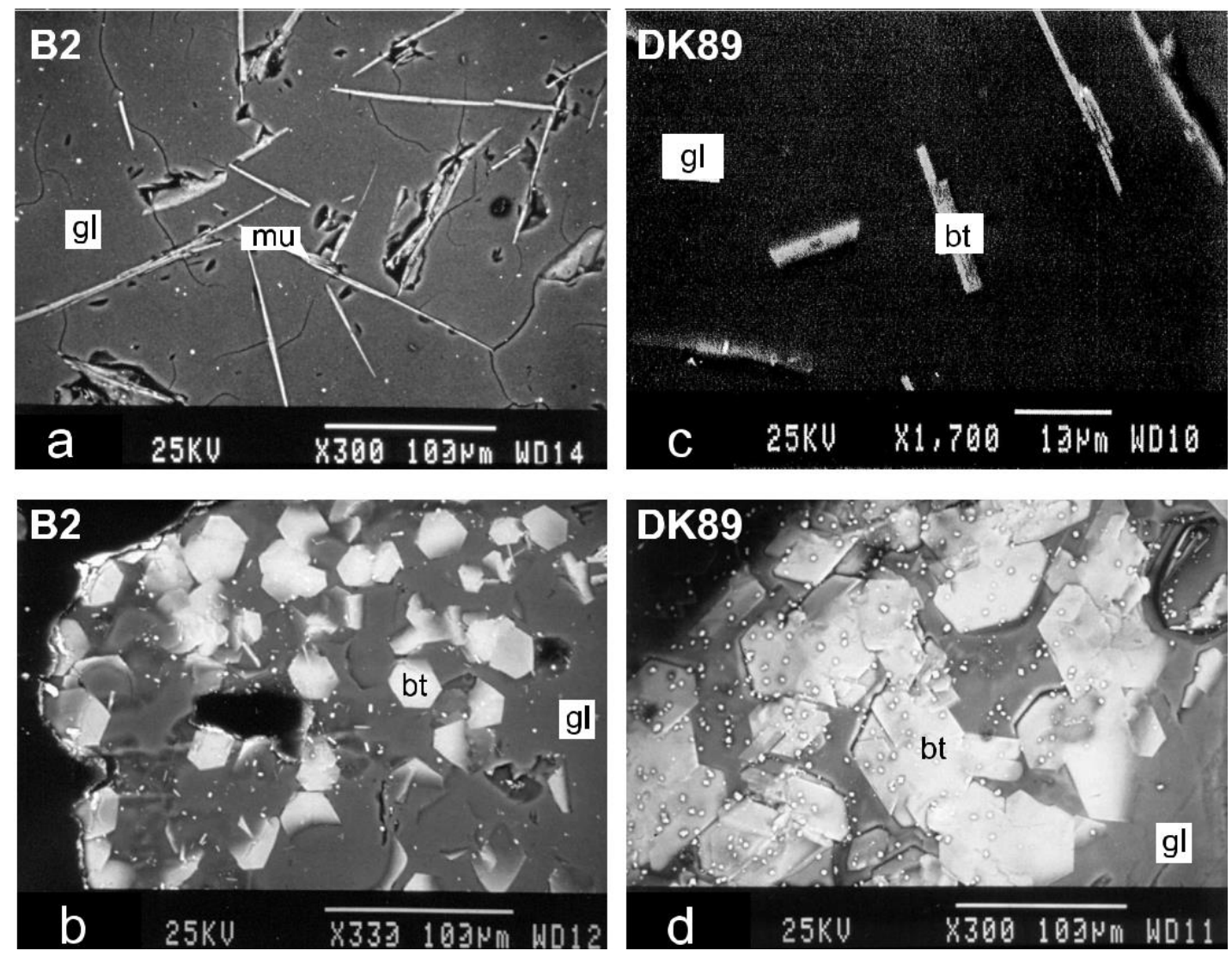

FIG. 1. SEM photomicrographs of representative experimental products. (a) Oxidizing B2 experiment showing long muscovite crystals embedded in glass; charge \#4 (Table 2). (b) Reducing B2 experiment showing large biotite crystals embedded in glass; charge \#39 (Table 2). (c) Oxidizing DK89 experiment showing biotite crystallized in charge \#28 (Table 3). (d) Reducing DK89 experiment showing large biotite crystals embedded in glass; charge \#46 (Table 3). gl: glass; bt: biotite; mu: muscovite. Experimental conditions in Tables 2 and 3.

contrast to the muscovite seeds, the biotite seeds were strongly reacted, as evidenced by their irregular shapes, markedly reduced sizes, presence of numerous magnetite crystals, and of a newly grown mica (textural type Snew) in zones 50-100 $\mathrm{lm}$ around the seeds (charge \#24, Tables 2, 4).

Structural formulae calculated on the basis of $22 \mathrm{O}$ yield Si (apfu) close to and generally above 6 (5.936.27) for the $\mathrm{C}$ micas, indicative of the presence of a phengitic component (Table 4). Octahedral Al amounts to 3.90-3.99 apfu. Sums of cations at the alkali site range from 1.82 to 1.99 apfu. About $30 \%$ of the hydroxyl site is occupied by $\mathrm{F}$. In the $\mathrm{Fe}_{\mathrm{t}} \mathrm{p} \mathrm{Mn} \mathrm{p}$ $\mathrm{Ti}-\mathrm{Al}^{\mathrm{VI}}$ versus $\mathrm{Mg}-\mathrm{Li}$ diagram (Fig. 2), constructed with Li calculated using equation [di 1] in Tischendorf et al. (1997), the C micas slightly depart from the muscovite endmember, being shifted toward lepidolite. Srim micas are shifted toward Li phengite and
Snew plot intermediate between the phengite and Liphengite fields, being far removed from the starting biotite seeds.

Under reducing conditions, only the $6208 \mathrm{C}$ experiments crystallized mica, the 700 (Table 2) and 750 8C (Lahlafi 1997) charges being mica-free. Quartz and feldspars (and also magnetite) are absent in the $6208 \mathrm{C}$ product, suggesting that the quartz and feldspar saturation curves are more depressed under reducing than under oxidizing conditions (Pichavant et al. 1987a). Mica amounts to about 5 wt.\% of the charge. It reaches a maximum size of $30-40 \mathrm{~lm}$ in experiments with the preconditioning dwell (Table 2; Fig. 1b).

The C-type micas are chemically very homogeneous (Table 4). These are biotites with elevated $\mathrm{Al}_{2} \mathrm{O}_{3}$ (21-22.5 wt.\%) and $\mathrm{FeO}_{\mathrm{t}}(21-22.5$ wt.\%), F . 2 wt. $\%$, and $\mathrm{X}_{\mathrm{Fe}} \sim 0.8 . \mathrm{TiO}_{2}$ and, to a lesser extent, 


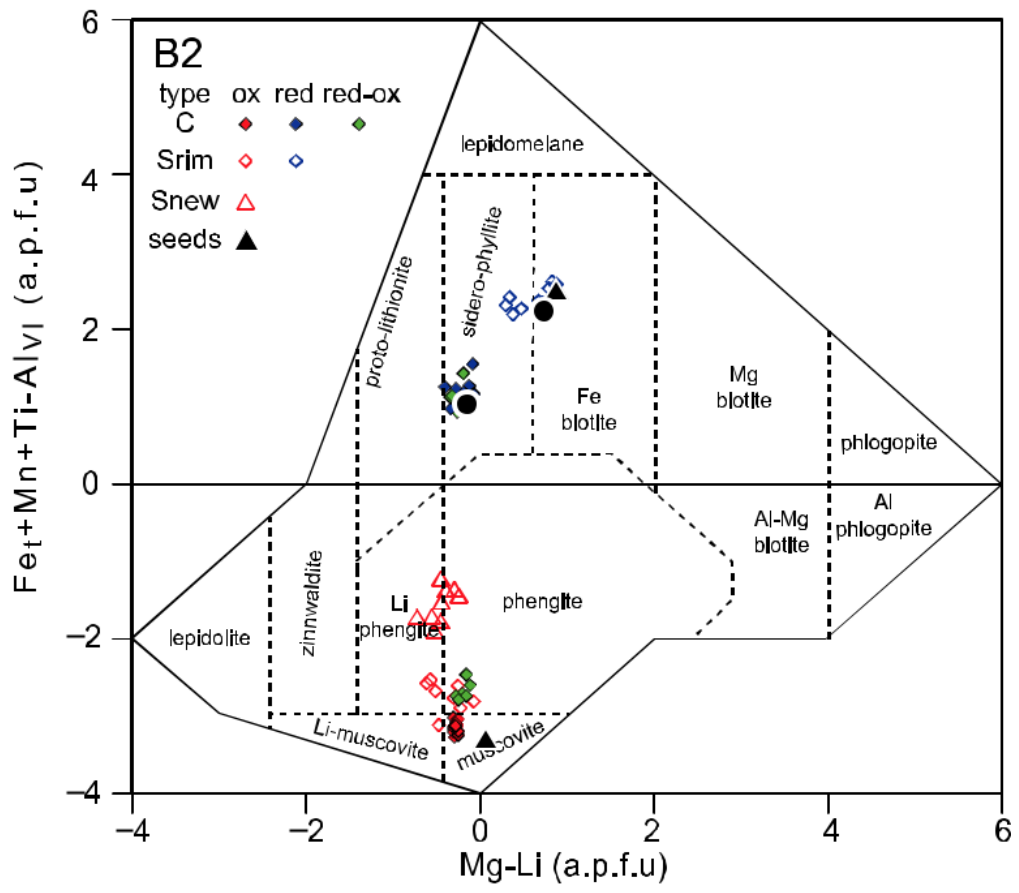

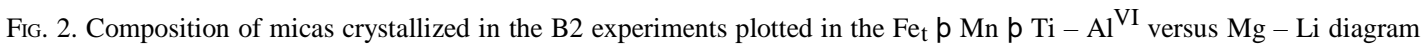
(Tischendorf et al. 1997). Lithium contents of muscovite and biotite estimated using equation [di 1] and [tri 1] respectively (Tischendorf et al. 1997). The experimental data points are distinguished on the basis of redox conditions (ox: oxidized; red: reduced; red-ox: two stage experiment) and textural type (C: mica crystallized spontaneously in the melt; Srim: rim composition of a seed, either muscovite or biotite; Snew: newly grown mica crystallized in reaction zone around a seed, either muscovite or biotite). See text for details. Compositions of muscovite and biotite seeds (black triangles) from Table 1. The large black circles are biotite microphenocrysts in the Macusani obsidian glass (Pichavant et al. 1988).

$\mathrm{MgO}$ are low $(0.2-0.5$ and $1.5-2.5$ wt. $\%$, respectively). Few $\mathrm{Li}$ and $\mathrm{Be}$ analyses are available (respectively 1508 and 30 ppm, Table 4).

The muscovite seeds showed no evidence of reaction (steady sizes, sharp seed-glass interfaces, lack of breakdown phases) in charge \#44 (Table 2), and no core-rim zonation was detected. The biotite seeds also appeared unreacted, although the rims ( $\mathrm{S}$ rim type) were found to be enriched in $\mathrm{F}$ (up to 2.3 wt.\% F) relative to the residual cores $(0.9 \mathrm{wt} . \% \mathrm{~F})$. It should be noted that the reduced experiments were on average much shorter than the oxidized ones due to the short lifetime of the CCO buffer. Textural relations around the muscovite seeds could indicate muscovite stability or, alternatively, sluggish muscovite breakdown. For the biotite seeds, the textural relations are interpreted to indicate biotite stability.

In the $\mathrm{Fe}_{\mathrm{t}} \mathrm{p} \mathrm{Mn} \mathrm{p} \mathrm{Ti}-\mathrm{Al}^{\mathrm{VI}}$ versus $\mathrm{Mg}-\mathrm{Li}$ diagram (Fig. 2), constructed with $\mathrm{Li}$ calculated using equation [tri 1] of Tischendorf et al. (1997), the C micas form a welldefined compositional group in the siderophyllite field and approach the protolithionite field, whereas the Srim compositions overlap with the starting biotite seed.

The two-stage reduced then oxidized experiment \#77 (Table 2) yielded a phase assemblage with mica, apatite, and magnetite plus low amounts of quartz and feldspar phases. The mica (up to $80 \mathrm{~lm}$ in size) is remarkably zoned (Fig. 3a). Core compositions are biotites rich in $\mathrm{Al}_{2} \mathrm{O}_{3}$ (22 wt.\%) and $\mathrm{FeO}_{\mathrm{t}}(20-22$ wt.\%) with $\sim 2$ wt.\% F (Fig. 3b). $\mathrm{XFe}_{\mathrm{Fe}}$ are $\sim 0.8$ whereas $\mathrm{TiO}_{2}(0.2-0.4$ wt.\%) and $\mathrm{MgO}(1.8-2.2$ wt. $\%)$ are both low. This means the core compositions are identical to type-C siderophyllites in the reduced B2 charges (Fig. 2). The rims have higher $\mathrm{Al}_{2} \mathrm{O}_{3}$ (29-33 wt.\%), lesser $\mathrm{F}\left(1-1.5\right.$ wt.\%) and $\mathrm{FeO}_{\mathrm{t}}$ (4-6 wt.\%), and low $\mathrm{TiO}_{2}, \mathrm{Na}_{2} \mathrm{O}$, and $\mathrm{MgO}$, closely approaching compositions of type- $\mathrm{C}$ muscovites in the oxidized $\mathrm{B} 2$ charges (Table 4), although the two groups do not exactly overlap (Fig. 2). The transition between core and rim is sharp, occurring over less than $10 \mathrm{~lm}$ (Fig. $3 \mathrm{a}$; b). Beryllium concentrations $(\sim 100 \mathrm{ppm})$ are similar between the two zones, whereas $\mathrm{F}$ and $\mathrm{Li}$ both drop by a factor of $\sim 2$ from core to rim (Table 4 ). 

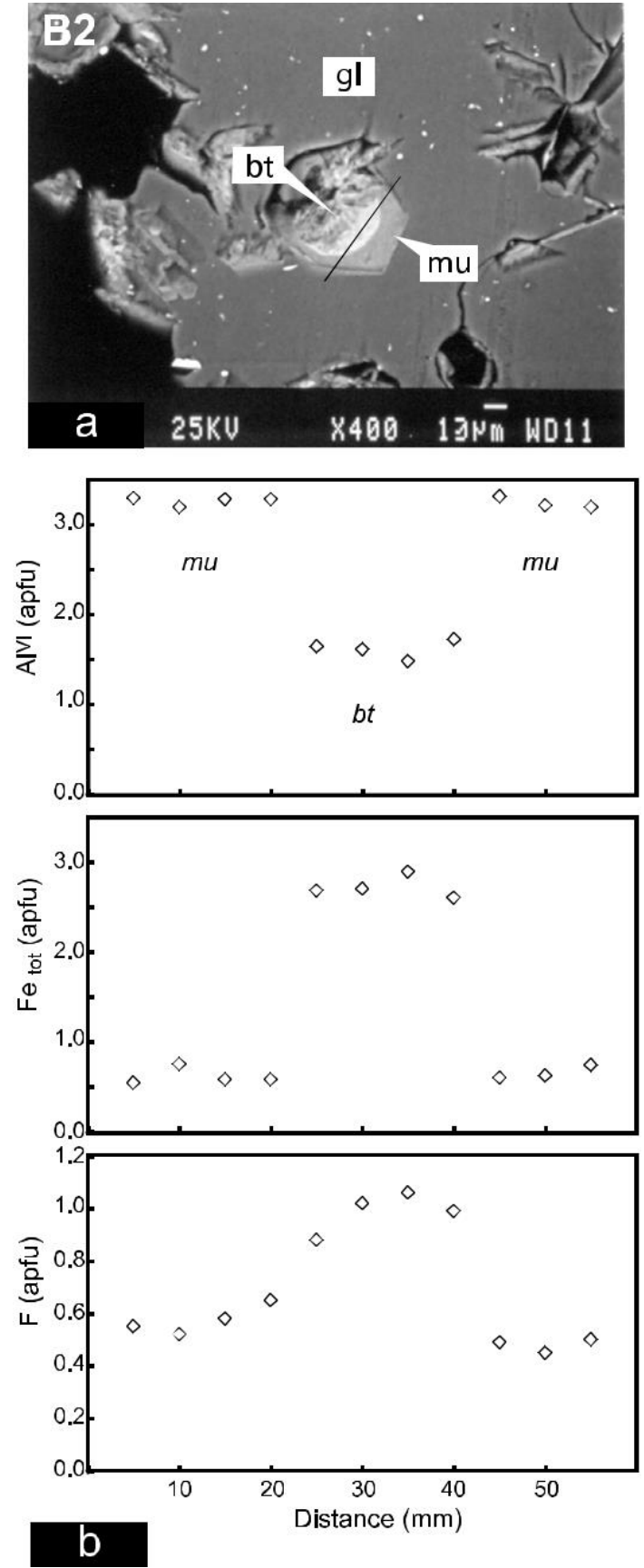

FIG. 3. (a) SEM photomicrograph of mica in the two-stage reducing-oxidizing experiment \#77 (see Table 2 and text for details). gl: glass; bt: biotite; mu: muscovite. (b) Electron microprobe traverse showing the compositional contrast in $\mathrm{Al}^{\mathrm{VI}}, \mathrm{Fe}$, and $\mathrm{F}$ (atomic concentrations) between the biotite core and the muscovite shell. The black straight line in (a) shows the location of the traverse.
Manaslu (DK89) experiments

Phase assemblages and mica compositions are reported in Tables 3 and 5, respectively. Under oxidizing conditions, biotite is the only phase to crystallize at $7208 \mathrm{C}$ (charge \#27). It makes up about $5 \mathrm{wt} . \%$ of the charge, appearing as idiomorphic $\sim 60$ $1 \mathrm{~m}$ crystals homogeneously dispersed in the glass. At $7008 \mathrm{C}$ and for $\mathrm{aH}_{2} \mathrm{O} 1 / 41$ (charge \#28), biotite is joined by K-feldspar. Upon decreasing $\mathrm{aH}_{2} \mathrm{O}$, additional phases enter the crystallization sequence: quartz, plagioclase, and then muscovite in the charge with the lowest $\mathrm{aH}_{2} \mathrm{O}(\# 31$, Table 3). Biotites and muscovites have sizes of $\sim 15$ (Fig. 1c) and $\sim 30-40$ $1 \mathrm{~m}$, respectively. In charge \#32, which started from the enriched DK89 glass, biotite is absent.

Type-C biotites at 720 and $7008 \mathrm{C}$ have similar compositions (Table 5). They are aluminous (16.5-22 wt. $\% \mathrm{Al}_{2} \mathrm{O}_{3}$ ), relatively $\mathrm{TiO}_{2}$-rich (1.5-3.5 wt.\%), and F-poor (,0.3 wt.\%, Table 5). $\mathrm{FeO}_{\mathrm{t}}$ is elevated (18.521.5 wt.\%) and $\mathrm{MgO}$ is relatively high but variable (5- 10 wt.\%), yielding $\mathrm{X}_{\mathrm{Fe}}$ from 0.5 to 0.7 . The low $\mathrm{Li}$ and $\mathrm{Be}$ (respectively 223 and $30 \mathrm{ppm}$, Table 5) reflect the light-element concentrations of the starting melt. In the seeded 720 8C charge (\#33), type-C biotites away from the seeds are similar to $\mathrm{C}$ biotites in the non-seeded charges. Biotite seeds appear stable, although rims (textural type Srim) are depleted in Fe and $\mathrm{F}$ and strongly enriched in $\mathrm{Li}$ and $\mathrm{Be}$ compared to cores. Muscovite seeds are extensively reacted to a complex assemblage (100-300 $\mathrm{lm}$ wide) that includes hercy-nitic spinel, corundum, mullite, and biotite as newly formed phases. Newly formed biotites (textural type Snew) have compositions similar to the type-C biotites (Table 5).

Type-C biotites have octahedral cations summing to $\sim 5.5 \mathrm{apfu}$, indicating departure from a strictly trioctahedral character. In the Fet $\mathrm{p} \mathrm{Mn} \mathrm{p} \mathrm{Ti}-\mathrm{Al}^{\mathrm{VI}}$ versus $\mathrm{Mg}-\mathrm{Li}$ diagram (Fig. 4), constructed with $\mathrm{Li}$ calculated using equation [tri 1] in Tischendorf et al. (1997), C biotites continuously evolve from $\mathrm{Mg}$ biotite, $\mathrm{Fe}$ biotite to siderophyllite. Compositional evolutions with decreasing temperature or $\mathrm{aH}_{2} \mathrm{O}$ (and so increasing charge crystallinities) are controlled by three main substitutions: $\mathrm{Mg} 1 / 4 \mathrm{Fe}, \mathrm{M}$ (mainly $\mathrm{Mg}$, $\mathrm{Fe}) \mathrm{Si} 1 / 42 \mathrm{Al}^{\mathrm{IV}}$, and $3 \mathrm{M} 1 / 42 \mathrm{Al}{ }^{\mathrm{VI}}$. The most Mg-rich biotites correspond to the $\mathrm{H}_{2} \mathrm{O}$-saturated charges at 720 and 700 8C (respectively \#27 and \#28) and the most evolved (highest $\mathrm{X}_{\mathrm{Fe}} \sim 0.7$ and $\mathrm{Al}^{\mathrm{VI}}$ ) to the muscovite-bearing charge \#31. Muscovite in that charge is close to the endmember composition, overlapping with the composition of the starting muscovite seeds (Fig. 4).

Under reducing conditions at $7208 \mathrm{C}$, again biotite is the only phase to crystallize (Table 3 ). Biotite 
TABLE 4. COMPOSITIONS OF MICAS IN THE B2 EXPERIMENTS

\begin{tabular}{|c|c|c|c|c|c|c|c|c|c|c|c|}
\hline \multirow{3}{*}{$\begin{array}{l}\text { Experiment } \\
\text { Charge } \#^{1} \\
\text { Textural type }\end{array}$} & \multicolumn{6}{|c|}{ Oxidizing } & \multicolumn{3}{|c|}{ Reducing } & \multirow{2}{*}{\multicolumn{2}{|c|}{$\begin{array}{c}\text { Reducing-oxidizing } \\
77 \\
\end{array}$}} \\
\hline & \multirow{2}{*}{$\begin{array}{l}3 \\
\mathrm{C}\end{array}$} & \multirow{2}{*}{$\begin{array}{l}4 \\
\mathrm{C}\end{array}$} & \multirow{2}{*}{$\begin{array}{r}17 \\
C\end{array}$} & \multirow{2}{*}{$\begin{array}{c}20 \\
\text { Srim }\end{array}$} & \multirow{2}{*}{$\begin{array}{c}24 \\
\text { Srim }\end{array}$} & \multirow{2}{*}{$\begin{array}{c}24 \\
\text { Snew }\end{array}$} & \multirow{2}{*}{$\begin{array}{l}38 \\
\mathrm{C}\end{array}$} & \multirow{2}{*}{$\begin{array}{l}39 \\
\mathrm{C}\end{array}$} & \multirow{2}{*}{$\begin{array}{l}40 \\
C\end{array}$} & & \\
\hline & & & & & & & & & & Core & Rim \\
\hline $\mathrm{SiO}_{2}$ (wt.\%) & 43.7 & 44.7 & 43.6 & 43.2 & 43.5 & 43.9 & 37.5 & 36.8 & 38.2 & 38.0 & 46.2 \\
\hline $\mathrm{TiO}_{2}$ & 0.24 & 0.02 & 0.18 & 0.32 & 0.00 & 1.00 & 0.32 & 0.21 & 0.41 & 0.30 & 0.26 \\
\hline $\mathrm{Al}_{2} \mathrm{O}_{3}$ & 34.4 & 33.5 & 34.26 & 30.9 & 30.8 & 25.7 & 22.5 & 22.2 & 21.1 & 22.4 & 32.2 \\
\hline $\begin{array}{l}\mathrm{FeO}_{\mathrm{t}} \\
\mathrm{MnO}\end{array}$ & $\begin{array}{l}2.69 \\
0.02\end{array}$ & $\begin{array}{l}3.74 \\
0.12\end{array}$ & $\begin{array}{l}2.92 \\
0.04\end{array}$ & $\begin{array}{l}2.78 \\
0.00\end{array}$ & $\begin{array}{l}5.22 \\
0.14\end{array}$ & $\begin{array}{l}6.75 \\
0.14\end{array}$ & $\begin{array}{c}20.9 \\
0.24\end{array}$ & $\begin{array}{c}22.3 \\
0.33\end{array}$ & $\begin{array}{l}21.3 \\
0.33\end{array}$ & $\begin{array}{l}21.6 \\
0.43\end{array}$ & $\begin{array}{l}5.15 \\
0.16\end{array}$ \\
\hline $\mathrm{MgO}$ & 0.39 & 0.29 & 0.49 & 1.78 & 0.65 & 4.47 & 1.76 & 2.07 & 2.54 & 2.12 & 0.59 \\
\hline $\mathrm{Na}_{2} \mathrm{O}$ & 0.89 & 0.81 & 0.88 & 0.55 & 0.64 & 0.76 & 0.51 & 0.32 & 0.49 & 0.41 & 0.76 \\
\hline $\begin{array}{l}\mathrm{K}_{2} \mathrm{O} \\
\mathrm{F}\end{array}$ & $\begin{array}{l}9.88 \\
1.38\end{array}$ & $\begin{array}{l}9.75 \\
1.37\end{array}$ & $\begin{array}{c}10.0 \\
1.37\end{array}$ & $\begin{array}{c}10.0 \\
2.10\end{array}$ & $\begin{array}{l}9.85 \\
2.48\end{array}$ & $\begin{array}{l}9.51 \\
3.64\end{array}$ & $\begin{array}{l}9.17 \\
2.31\end{array}$ & $\begin{array}{l}9.08 \\
2.80\end{array}$ & $\begin{array}{l}9.05 \\
2.74\end{array}$ & $\begin{array}{l}9.24 \\
2.17\end{array}$ & $\begin{array}{l}9.81 \\
1.36\end{array}$ \\
\hline Total & 93.6 & 94.3 & 93.8 & 91.7 & 93.3 & 95.8 & 95.2 & 96.1 & 96.2 & 96.6 & 96.5 \\
\hline $\begin{array}{l}\mathrm{F}^{1 / 40} \\
\text { Total }\end{array}$ & $\begin{array}{l}0.58 \\
93.0\end{array}$ & $\begin{array}{c}0.58 \\
93.7\end{array}$ & $\begin{array}{l}0.58 \\
93.2^{2}\end{array}$ & $\begin{array}{l}0.88 \\
90.8\end{array}$ & $\begin{array}{l}1.00 \\
92.3\end{array}$ & $\begin{array}{l}1.53 \\
94.3\end{array}$ & $\begin{array}{c}0.97 \\
94.2\end{array}$ & $\begin{array}{l}1.18 \\
94.9\end{array}$ & $\begin{array}{l}1.15 \\
95.0\end{array}$ & $\begin{array}{l}0.91 \\
95.7\end{array}$ & $\begin{array}{l}0.57 \\
95.9\end{array}$ \\
\hline $\begin{array}{l}\mathrm{Li}(p p m) \\
\mathrm{Be}\end{array}$ & $\begin{array}{l}\text { nd } \\
\text { nd }\end{array}$ & $\begin{array}{r}809 \\
30\end{array}$ & $\begin{array}{l}983 \\
150\end{array}$ & $\begin{array}{l}3299 \\
1180\end{array}$ & $\begin{array}{l}\text { nd } \\
\text { nd }\end{array}$ & $\begin{array}{l}\text { nd } \\
\text { nd }\end{array}$ & $\begin{array}{l}\text { nd } \\
\text { nd }\end{array}$ & $\begin{array}{r}1508 \\
30\end{array}$ & $\begin{array}{l}\text { nd } \\
\text { nd }\end{array}$ & $\begin{array}{l}978 \\
100\end{array}$ & $\begin{array}{l}555 \\
104\end{array}$ \\
\hline $\begin{array}{l}\text { Si (cation) }{ }^{2} \\
\mathrm{Al}^{\mathrm{IV}}\end{array}$ & $\begin{array}{l}5.97 \\
2.03\end{array}$ & $\begin{array}{l}6.09 \\
1.91\end{array}$ & $\begin{array}{l}5.97 \\
2.03\end{array}$ & $\begin{array}{l}6.07 \\
1.93\end{array}$ & $\begin{array}{l}6.06 \\
1.94\end{array}$ & $\begin{array}{l}6.04 \\
1.96\end{array}$ & $\begin{array}{l}5.67 \\
2.33\end{array}$ & $\begin{array}{l}5.55 \\
2.45\end{array}$ & $\begin{array}{l}5.73 \\
2.27\end{array}$ & $\begin{array}{l}5.67 \\
2.33\end{array}$ & $\begin{array}{l}6.19 \\
1.81\end{array}$ \\
\hline $\begin{array}{l}\mathrm{Al}^{\mathrm{Vl}} \\
\mathrm{Ti}\end{array}$ & $\begin{array}{l}3.53 \\
0.02\end{array}$ & $\begin{array}{l}3.47 \\
0.00\end{array}$ & $\begin{array}{l}3.50 \\
0.02\end{array}$ & $\begin{array}{l}3.17 \\
0.03\end{array}$ & $\begin{array}{l}3.13 \\
0.00\end{array}$ & $\begin{array}{l}2.22 \\
0.10\end{array}$ & $\begin{array}{l}1.67 \\
0.04\end{array}$ & $\begin{array}{l}1.50 \\
0.02\end{array}$ & $\begin{array}{l}1.45 \\
0.05\end{array}$ & $\begin{array}{l}1.61 \\
0.03\end{array}$ & $\begin{array}{l}3.28 \\
0.03\end{array}$ \\
\hline $\mathrm{Fe}$ & 0.31 & 0.43 & 0.33 & 0.33 & 0.61 & 0.78 & 2.64 & 2.82 & 2.67 & 2.70 & 0.58 \\
\hline $\mathrm{Mn}$ & 0.00 & 0.01 & 0.00 & 0.00 & 0.02 & 0.02 & 0.03 & 0.04 & 0.04 & 0.05 & 0.02 \\
\hline $\mathrm{Mg}$ & 0.08 & 0.06 & 0.10 & 0.37 & 0.14 & 0.92 & 0.40 & 0.47 & 0.57 & 0.47 & 0.12 \\
\hline $\mathrm{Na}$ & 0.24 & 0.21 & 0.23 & 0.15 & 0.17 & 0.20 & 0.15 & 0.09 & 0.13 & 0.12 & 0.20 \\
\hline K & 1.73 & 1.69 & 1.75 & 1.80 & 1.75 & 1.67 & 1.77 & 1.75 & 1.73 & 1.76 & 1.68 \\
\hline $\mathrm{F}$ & 0.60 & 0.59 & 0.59 & 0.93 & 1.09 & 1.59 & 1.10 & 1.34 & 1.30 & 1.02 & 0.58 \\
\hline $\mathrm{Fe}^{2 \mathrm{p}}$ & 0.25 & 0.34 & 0.26 & 0.26 & 0.49 & 0.62 & 2.11 & 2.26 & 2.13 & 2.16 & 0.46 \\
\hline $\mathrm{Fe}^{3 p}$ & 0.06 & 0.09 & 0.07 & 0.07 & 0.12 & 0.16 & 0.53 & 0.56 & 0.53 & 0.54 & 0.12 \\
\hline
\end{tabular}

Major element compositions by electron microprobe. Lithium and Be concentrations by nuclear microprobe.

1 See Table 2 for experimental conditions and starting compositions.

${ }^{2}$ Structural formulae calculated on the basis of $22 \mathrm{O}$ atoms, with Li not considered in the calculations. $\mathrm{Fe}^{2 \mathrm{p}}$ and $\mathrm{Fe}^{3 \mathrm{p}}$ calculated after Redhammer et al. (1993, 2000).

nd: not determined.

C: mica crystallized within the melt. For seeded charges, this corresponds to mica crystallized in zones away from the seeds.

Srim: outer rim of muscovite seed.

Snew: newly grown mica in reaction zone around biotite seeds.

proportions amount up to $3-5 \mathrm{wt} \%$ of the charge and crystal sizes reach $.50 \mathrm{~lm}$ (Fig. 1d). Type-C biotites in the reduced charge \#46 are aluminous (18 wt.\% $\mathrm{Al}_{2} \mathrm{O}_{3}$ ), relatively $\mathrm{TiO}_{2}$-rich $(3 \mathrm{wt} . \%)$ and F-poor $(, 0.2$ wt.\%, Table 5). $\mathrm{FeO}_{\mathrm{t}}$ concentrations are relatively high (17 wt.\%) and $\mathrm{MgO}$ attains 11 wt.\%, yielding a $\mathrm{X}_{\mathrm{Fe}}$ of $\sim 0.4$. Lithium and Be concentrations (204 and $181 \mathrm{ppm}$, respectively) remain low. Type-C biotites plot in the $\mathrm{Mg}$ biotite field of the $\mathrm{Fe}_{\mathrm{t}} \mathrm{p} \mathrm{Mn} \mathrm{p}$ Ti

$-\mathrm{Al}^{\mathrm{VI}}$ versus $\mathrm{Mg}-\mathrm{Li}$ diagram (Fig. 4), overlapping with the most Mg-rich biotites of the oxidized charges. Newly-formed (type Snew) biotites in reaction zones around muscovite seeds (charge \#48) are slightly more aluminous and ferrous than type-C biotites. In the muscovite and biotite-seeded charge \#49, performed with the enriched DK89 starting glass, newly grown biotites (type Snew) are lower in $\mathrm{Al}_{2} \mathrm{O}_{3}$ and higher in $\mathrm{F}$ than the type-C biotites, and they are also strongly $\mathrm{Li}$-and Be-enriched. In that charge, the rims of biotite seeds (type Srim) are also Li- and Be-rich (Table 5).

Glass composition and mica-melt $\mathrm{F}, \mathrm{Li}, \mathrm{Be}$ partitioning

Glass compositions from selected charges are given in Table 6. There are minor differences (e.g., $\mathrm{Na}_{2} \mathrm{O}$ 
TABLE 5. COMPOSITIONS OF MICAS IN THE DK89 EXPERIMENTS

\begin{tabular}{|c|c|c|c|c|c|c|c|c|c|c|c|c|}
\hline \multirow{2}{*}{$\begin{array}{c}\text { Experiment } \\
\text { Charge \# }{ }^{1} \\
\text { Textural type }\end{array}$} & \multicolumn{8}{|c|}{ Oxidizing } & \multicolumn{4}{|c|}{ Reducing } \\
\hline & $\begin{array}{c}27^{2} \\
C\end{array}$ & $\begin{array}{l}28 \\
\mathrm{C}\end{array}$ & $\begin{array}{r}29 \\
\mathrm{C}\end{array}$ & $\begin{array}{r}31 \\
\mathrm{C}\end{array}$ & $\begin{array}{c}31 \\
\mathrm{C}\end{array}$ & $\begin{array}{l}33 \\
\mathrm{C}\end{array}$ & $\begin{array}{c}33 \\
\text { Srim }\end{array}$ & $\begin{array}{c}33 \\
\text { Snew }\end{array}$ & $\begin{array}{l}46 \\
\mathrm{C}\end{array}$ & $\begin{array}{r}48 \\
\text { Snew }\end{array}$ & $\begin{array}{c}49 \\
\text { Snew }\end{array}$ & $\begin{array}{c}49 \\
\text { Srim }\end{array}$ \\
\hline $\mathrm{SiO}_{2}$ (wt.\%) & 35.8 & 36.5 & 37.1 & 34.9 & 44.7 & 35.0 & 35.0 & 35.0 & 36.5 & 34.9 & 38.7 & 37.9 \\
\hline $\mathrm{TiO}_{2}$ & 2.58 & 1.43 & 2.27 & 3.58 & 0.79 & 2.55 & 2.67 & 2.32 & 3.15 & 2.20 & 2.80 & 3.39 \\
\hline $\mathrm{Al}_{2} \mathrm{O}_{3}$ & 17.0 & 17.5 & 16.7 & 20.7 & 35.7 & 21.9 & 18.6 & 22.0 & 18.2 & 21.9 & 14.7 & 15.8 \\
\hline $\begin{array}{l}\mathrm{FeO}_{\mathrm{t}} \\
\mathrm{MnO}\end{array}$ & $\begin{array}{c}18.5 \\
0.05\end{array}$ & $\begin{array}{c}20.5 \\
0.23\end{array}$ & $\begin{array}{c}21.0 \\
0.03\end{array}$ & $\begin{array}{c}21.5 \\
0.46\end{array}$ & $\begin{array}{l}2.44 \\
0.00\end{array}$ & $\begin{array}{l}19.5 \\
0.06\end{array}$ & $\begin{array}{c}21.3 \\
0.14\end{array}$ & $\begin{array}{c}18.7 \\
0.05\end{array}$ & $\begin{array}{c}16.8 \\
0.09\end{array}$ & $\begin{array}{c}18.3 \\
0.04\end{array}$ & $\begin{array}{c}19.3 \\
0.11\end{array}$ & $\begin{array}{l}19.3 \\
0.11\end{array}$ \\
\hline $\mathrm{MgO}$ & 10.4 & 10.1 & 8.68 & 5.22 & 0.53 & 5.76 & 6.44 & 6.99 & 11.0 & 7.28 & 7.30 & 8.24 \\
\hline $\mathrm{Na}_{2} \mathrm{O}$ & 0.35 & 0.38 & 0.65 & 0.21 & 1.04 & 0.41 & 0.27 & 0.32 & 0.74 & 0.29 & 0.22 & 0.28 \\
\hline $\begin{array}{l}\mathrm{K}_{2} \mathrm{O} \\
\mathrm{F}\end{array}$ & $\begin{array}{l}9.08 \\
0.08\end{array}$ & $\begin{array}{l}9.29 \\
0.08\end{array}$ & $\begin{array}{l}9.28 \\
0.22\end{array}$ & $\begin{array}{l}9.22 \\
0.19\end{array}$ & $\begin{array}{c}10.5 \\
0.24\end{array}$ & $\begin{array}{l}9.49 \\
0.17\end{array}$ & $\begin{array}{l}9.13 \\
0.19\end{array}$ & $\begin{array}{l}9.22 \\
0.06\end{array}$ & $\begin{array}{l}9.43 \\
0.12\end{array}$ & $\begin{array}{l}9.34 \\
0.22\end{array}$ & $\begin{array}{l}9.26 \\
2.92\end{array}$ & $\begin{array}{l}9.29 \\
2.94\end{array}$ \\
\hline Total & 93.8 & 96.0 & 96.0 & 96.0 & 96.0 & 94.8 & 93.7 & 94.7 & 96.0 & 94.4 & 95.3 & 97.2 \\
\hline $\begin{array}{l}\mathrm{F}^{1 / 4 \mathrm{O}} \\
\text { Total }\end{array}$ & $\begin{array}{c}0.02 \\
93.8\end{array}$ & $\begin{array}{l}0.03 \\
96.0\end{array}$ & $\begin{array}{c}0.09 \\
95.9\end{array}$ & $\begin{array}{c}0.08 \\
95.9\end{array}$ & $\begin{array}{l}0.10 \\
95.9\end{array}$ & $\begin{array}{l}0.07 \\
94.7\end{array}$ & $\begin{array}{l}0.08 \\
93.6\end{array}$ & $\begin{array}{l}0.03 \\
94.7\end{array}$ & $\begin{array}{l}0.05 \\
95.9\end{array}$ & $\begin{array}{l}0.09 \\
94.3\end{array}$ & $\begin{array}{c}1.23 \\
94.1\end{array}$ & $\begin{array}{l}1.24 \\
96.0\end{array}$ \\
\hline $\begin{array}{l}\mathrm{Li}(\mathrm{ppm}) \\
\mathrm{Be}\end{array}$ & $\begin{array}{r}223 \\
30\end{array}$ & $\begin{array}{l}\text { nd } \\
\text { nd }\end{array}$ & $\begin{array}{l}\text { nd } \\
\text { nd }\end{array}$ & $\begin{array}{l}\text { nd } \\
\text { nd }\end{array}$ & $\begin{array}{l}\text { nd } \\
\text { nd }\end{array}$ & $\begin{array}{l}\text { nd } \\
\text { nd }\end{array}$ & $\begin{array}{l}3606 \\
1457\end{array}$ & $\begin{array}{l}513 \\
251\end{array}$ & $\begin{array}{l}204 \\
181\end{array}$ & $\begin{array}{l}\text { nd } \\
\text { nd }\end{array}$ & $\begin{array}{r}4366 \\
678\end{array}$ & $\begin{array}{l}5500 \\
1294\end{array}$ \\
\hline $\begin{array}{l}\mathrm{Si} \text { (cation) } \\
\mathrm{Al}^{\mathrm{IV}}\end{array}$ & $\begin{array}{l}5.52 \\
2.48\end{array}$ & $\begin{array}{l}5.54 \\
2.46\end{array}$ & $\begin{array}{l}5.65 \\
2.35\end{array}$ & $\begin{array}{l}5.32 \\
2.68\end{array}$ & $\begin{array}{l}5.97 \\
2.03\end{array}$ & $\begin{array}{l}5.34 \\
2.66\end{array}$ & $\begin{array}{l}5.47 \\
2.53\end{array}$ & $\begin{array}{l}5.32 \\
2.68\end{array}$ & $\begin{array}{l}5.44 \\
2.56\end{array}$ & $\begin{array}{l}5.31 \\
2.69\end{array}$ & $\begin{array}{l}5.85 \\
2.15\end{array}$ & $\begin{array}{l}5.63 \\
2.37\end{array}$ \\
\hline $\begin{array}{l}\mathrm{Al}^{\mathrm{VI}} \\
\mathrm{Ti}\end{array}$ & $\begin{array}{l}0.60 \\
0.30\end{array}$ & $\begin{array}{l}0.67 \\
0.16\end{array}$ & $\begin{array}{l}0.64 \\
0.26\end{array}$ & $\begin{array}{l}1.04 \\
0.41\end{array}$ & $\begin{array}{l}3.6 \\
0.08\end{array}$ & $\begin{array}{l}1.28 \\
0.29\end{array}$ & $\begin{array}{l}0.89 \\
0.31\end{array}$ & $\begin{array}{l}1.26 \\
0.27\end{array}$ & $\begin{array}{l}0.66 \\
0.35\end{array}$ & $\begin{array}{l}1.24 \\
0.25\end{array}$ & $\begin{array}{l}0.47 \\
0.32\end{array}$ & $\begin{array}{l}0.39 \\
0.38\end{array}$ \\
\hline $\mathrm{Fe}$ & 2.38 & 2.61 & 2.67 & 2.74 & 0.27 & 2.48 & 2.78 & 2.38 & 2.09 & 2.32 & 2.45 & 2.39 \\
\hline $\mathrm{Mn}$ & 0.01 & 0.03 & 0.00 & 0.06 & 0 & 0.01 & 0.02 & 0.01 & 0.01 & 0.00 & 0.01 & 0.01 \\
\hline $\mathrm{Mg}$ & 2.40 & 2.28 & 1.97 & 1.19 & 0.11 & 1.31 & 1.50 & 1.58 & 2.45 & 1.65 & 1.65 & 1.82 \\
\hline $\mathrm{Na}$ & 0.10 & 0.11 & 0.19 & 0.06 & 0.27 & 0.12 & 0.08 & 0.09 & 0.21 & 0.09 & 0.06 & 0.08 \\
\hline K & 1.78 & 1.80 & 1.80 & 1.79 & 1.79 & 1.85 & 1.82 & 1.79 & 1.80 & 1.81 & 1.79 & 1.76 \\
\hline $\mathrm{F}$ & 0.02 & 0.02 & 0.10 & 0.09 & 0.1 & 0.08 & 0.09 & 0.03 & 0.06 & 0.10 & 1.40 & 1.38 \\
\hline $\mathrm{Fe}^{2 \mathrm{p}}$ & 1.90 & 2.09 & 2.14 & 2.19 & 0.22 & 1.99 & 2.22 & 1.90 & 1.68 & 1.86 & 1.96 & 1.91 \\
\hline $\mathrm{Fe}^{3 p}$ & 0.48 & 0.52 & 0.53 & 0.55 & 0.05 & 0.50 & 0.56 & 0.48 & 0.42 & 0.46 & 0.49 & 0.48 \\
\hline
\end{tabular}

Major element compositions by electron microprobe. Lithium and Be concentrations by nuclear microprobe.

1 See Table 3 for experimental conditions and starting compositions.

${ }^{2}$ Average of eight analytical spots.

${ }^{3}$ Structural formulae calculated on the basis of $22 \mathrm{O}$ atoms. $\mathrm{Fe}^{2 \mathrm{p}}$ and $\mathrm{Fe}^{3 \mathrm{p}}$ calculated after Redhammer et al. (1993, 2000). nd: not determined.

C: mica crystallized within the melt. For seeded charges, this corresponds to mica crystallized in zones away from the seeds.

Srim: outer rim of biotite seed.

Snew: newly-grown biotite in reaction zone around either muscovite (\#33, \#48) or biotite (\#49) seeds.

concentrations) between experimental and starting glasses, interpreted to be analytical. The influence of seed addition on glass composition is apparent (e.g., \#17, \#33, \#48). Charges made with the $\mathrm{F}_{-}, \mathrm{Li}-$, and Be-enriched glasses also clearly stand out (\#20, \#49). Nevertheless, experimental glasses are essentially homogeneous for each composition and reflect the respective degrees of evolution of the two starting leucogranites. In terms of major elements, the $\mathrm{B} 2$ glasses, with higher $\mathrm{Al}_{2} \mathrm{O}_{3}, \mathrm{Na}_{2} \mathrm{O} / \mathrm{K}_{2} \mathrm{O}$, and $\mathrm{P}_{2} \mathrm{O}_{5}$, and lower $\mathrm{FeO}_{\mathrm{t}}, \mathrm{MgO}$, and $\mathrm{CaO}$ than the $\mathrm{DK} 89$ glasses, are the most chemically evolved.
Data on the partitioning of $\mathrm{F}$ between mica and melt are listed in Table 7 and illustrated in Figure 5a. Results for biotite and muscovite are contrasted. For biotite, data for the B2 charge \#39 and the enriched DK89 charge \#49 yield a biotite-melt $\mathrm{F}$ partition coefficient ( $\mathrm{D}^{\mathrm{F}}$ Biot/L) of $2.25 \mathrm{p} 0.07$. Broadly consistent values are obtained from the DK89 charges \#27 and \#46, but their low bulk F concentrations lead to high uncertainties on $\mathrm{D}^{\mathrm{F}}$ Biot/L. Biotite core in the two-stage experiment \#77 yields a slightly lower $\mathrm{D}^{\mathrm{F}}$ (1.56) which should be considered as a minimum since the biotite is armored by a muscovite shell and thus 


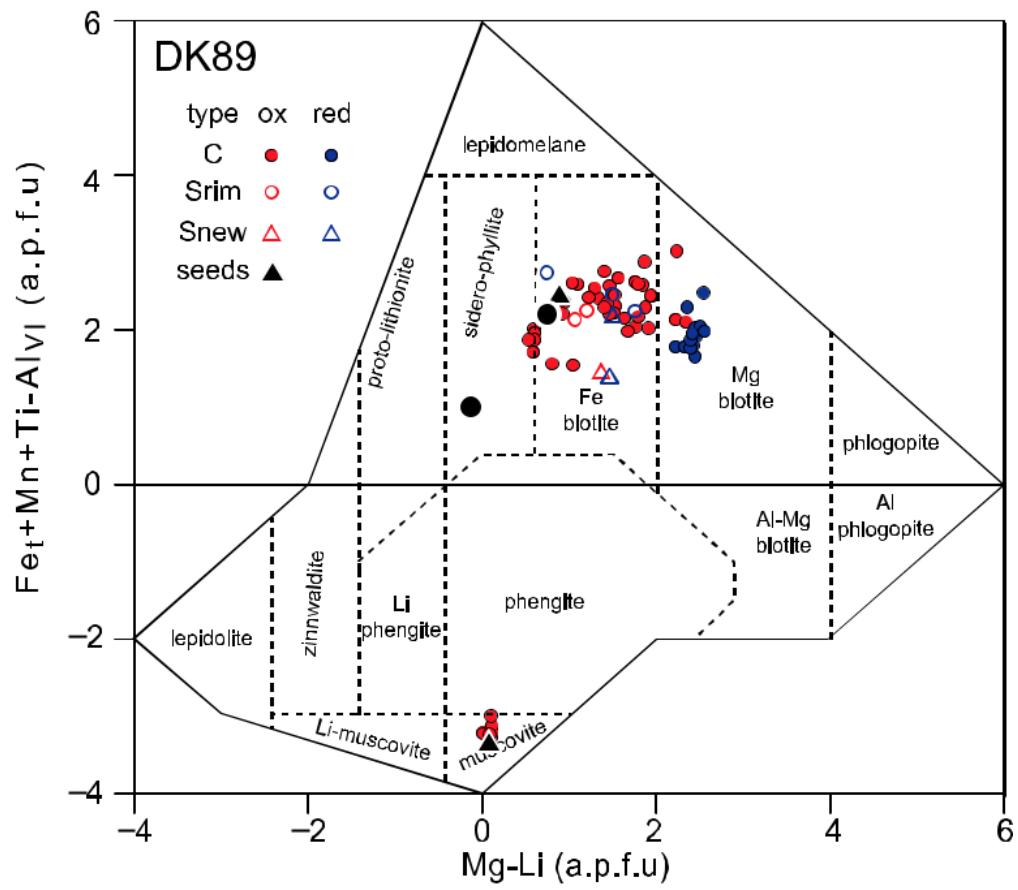

Fig. 4. Composition of micas crystallized in the DK89 experiments plotted in the $\mathrm{Fet}_{\mathrm{t}} \mathrm{p} \mathrm{Mn} \mathrm{p} \mathrm{Ti}-\mathrm{Al}^{\mathrm{VI}}$ versus $\mathrm{Mg}-\mathrm{Li}$ diagram (Tischendorf et al. 1997). Lithium contents of muscovite and biotite estimated using equation [di 1] and [tri 1] respectively (Tischendorf et al. 1997). The experimental data points are distinguished on the basis of redox conditions (ox: oxidized; red: reduced; red-ox: two stage experiment) and textural type (C: mica crystallized spontaneously in the melt; Srim: rim composition of a seed, either muscovite or biotite; Snew: newly grown mica crystallized in reaction zone around a seed, either muscovite or biotite). See text for details. Compositions of muscovite and biotite seeds (black triangles) from Table 1. The large black circles are biotite microphenocrysts in the Macusani obsidian glass (Pichavant et al. 1988).

was not in equilibrium with the melt (Fig. 3). The $\mathrm{D}^{\mathrm{F}}$ Biot/L above is identical to the value (2.3) obtained by Icenhower \& London (1995) at 650 8C. Lukkari \& Holtz (2007) measured a lower D ${ }^{\mathrm{F}}$ Biot/L (1.29 on average) between 625 and $7008 \mathrm{C}$. However, their experimental biotites are very Fe-rich (commonly .25 wt. $\%$ and up to .30 wt. $\% \mathrm{FeO}_{\mathrm{t}}$ ), and $\mathrm{Fe}-\mathrm{F}$ avoidance (Boukili et al. 2002) might explain their lower $\mathrm{D}^{\mathrm{F}}$ (see also Icenhower \& London 1997). Our D ${ }^{\mathrm{F}}$ Biot/L data, obtained at 620 and $7208 \mathrm{C}$, are identical within error, and no effect of $\mathrm{f}_{2}$ on $\mathrm{D}{ }^{\mathrm{F}} \mathrm{Biot} / \mathrm{L}$ can be distinguished. For muscovite, the oxidized B2 charges define a $\mathrm{D}^{\mathrm{F}} \mathrm{Mu} / \mathrm{L}$ of $1.02 \mathrm{p} 0.09$, less than the 1.8 determined by Icenhower \& London (1995). Our results imply a difference of a factor of $\sim 2-2.5$ between the $\mathrm{F}$ mineral/melt partition coefficient for biotite and muscovite.

$\mathrm{Li} \mathrm{mica/melt} \mathrm{partitioning} \mathrm{is} \mathrm{similar} \mathrm{to} \mathrm{F}$ in showing a clear difference between biotite and muscovite (Table 7; Fig. 5b). Combining the data for the biotitebearing $\mathrm{B} 2$ and $\mathrm{DK} 89$ charges yields $\mathrm{D}{ }^{\mathrm{Li}} \mathrm{Biot} / \mathrm{L} 1 / 4$ $0.55 \mathrm{p} 0.16$. The $\mathrm{B} 2$ charges $(6208 \mathrm{C})$ are associated with lower $\mathrm{D}{ }^{\mathrm{Li}}$, and the $\mathrm{DK} 89$ charges (720 8C) with higher $\mathrm{D}^{\mathrm{Li}}$, yet the limited number of data points (n $1 / 44)$ prevents definition of temperature dependence of $\mathrm{D}{ }^{\mathrm{Li}}$ Biot/L. The B2 muscovite-bearing charges yield $\mathrm{D}^{\mathrm{Li}} \mathrm{Mu} / \mathrm{L} 1 / 40.19 \mathrm{p} 0.05$. Our $\mathrm{D}^{\mathrm{Li}}$ are both significantly lower than those of Icenhower \& London (1995), who determined values of 1.7 and 0.8 , respectively, for biotite and muscovite at $6508 \mathrm{C}$. Interestingly, $\mathrm{D}^{\mathrm{Li}}$ Biot/Mu are similar (1.8 versus 2.1 ) in the two studies. There is a factor $\sim 2$ difference between $\mathrm{Li}$ concentrations in biotite and muscovite in the two-stage experiment \#77 (Table 7). Our results imply that crystallization of biotite and muscovite, either individually or in combination, concentrates $\mathrm{Li}$ in silicic melts, and that the influence of muscovite is stronger than that of biotite.

For Be, the biotite-bearing charges yield $\mathrm{D}{ }^{\mathrm{Be}} \mathrm{Biot} / \mathrm{L}$ $1 / 40.58$ p 0.21 and the muscovite-bearing charges $D^{\mathrm{Be}}$ $\mathrm{Mu} / \mathrm{L} \quad 1 / 4 \quad 1.35$ p 0.43 (Table 7, Fig. 5c). Beryllium concentrations are underestimated in muscovite from the oxidized B2 charge \#4 and in glass from the reduced DK89 charge \#46, these two charges being 
TABLE 6. COMPOSITIONS OF GLASSES

\begin{tabular}{|c|c|c|c|c|c|c|c|c|c|c|c|}
\hline \multirow{2}{*}{$\begin{array}{c}\text { Starting composition } \\
\text { Charge \# }\end{array}$} & \multicolumn{5}{|c|}{ B2 } & \multicolumn{6}{|c|}{ DK89 } \\
\hline & 41 & 17 & 20 & 39 & 77 & 27 & 31 & 33 & 46 & 48 & 49 \\
\hline $\mathrm{SiO}_{2}$ (wt.\%) & 74.4 & 72.7 & 73.8 & 74.8 & 74.3 & 74.0 & 75.7 & 72.9 & 74.1 & 72.6 & 72.6 \\
\hline $\mathrm{TiO}_{2}$ & 0.02 & 0.00 & 0.00 & 0.03 & 0.01 & 0.10 & 0.00 & 0.07 & 0.14 & 0.12 & 0.09 \\
\hline $\mathrm{Al}_{2} \mathrm{O}_{3}$ & 15.9 & 17.2 & 16.1 & 16.0 & 16.2 & 15.9 & 16.5 & 17.4 & 15.8 & 17.3 & 16.9 \\
\hline $\begin{array}{l}\mathrm{FeO}_{\mathrm{t}} \\
\mathrm{MnO}\end{array}$ & $\begin{array}{l}0.16 \\
0.11\end{array}$ & $\begin{array}{l}0.32 \\
0.10\end{array}$ & $\begin{array}{l}0.23 \\
0.10\end{array}$ & $\begin{array}{l}0.52 \\
0.09\end{array}$ & $\begin{array}{l}0.42 \\
0.07\end{array}$ & $\begin{array}{l}0.57 \\
0.06\end{array}$ & $\begin{array}{l}0.88 \\
0.00\end{array}$ & $\begin{array}{l}0.86 \\
0.07\end{array}$ & $\begin{array}{l}0.65 \\
0.05\end{array}$ & $\begin{array}{l}0.88 \\
0.06\end{array}$ & $\begin{array}{l}0.81 \\
0.08\end{array}$ \\
\hline $\mathrm{MgO}$ & 0.07 & 0.05 & 0.05 & 0.03 & 0.03 & 0.18 & 0.10 & 0.14 & 0.14 & 0.12 & 0.03 \\
\hline $\mathrm{CaO}$ & 0.11 & 0.10 & 0.12 & 0.27 & 0.22 & 0.93 & 0.25 & 0.95 & 0.95 & 0.93 & 0.71 \\
\hline $\mathrm{Na}_{2} \mathrm{O}$ & 3.70 & 3.69 & 3.78 & 3.26 & 3.47 & 3.64 & 3.05 & 3.02 & 3.43 & 3.55 & 3.04 \\
\hline $\mathrm{K}_{2} \mathrm{O}$ & 3.55 & 3.56 & 3.73 & 3.56 & 3.70 & 4.38 & 3.35 & 4.35 & 4.57 & 4.34 & 5.02 \\
\hline $\begin{array}{l}\mathrm{P}_{2} \mathrm{O}_{5} \\
\mathrm{~F}\end{array}$ & $\begin{array}{l}1.20 \\
1.35\end{array}$ & $\begin{array}{l}1.45 \\
1.50\end{array}$ & $\begin{array}{l}1.06 \\
1.84\end{array}$ & $\begin{array}{l}0.75 \\
1.25\end{array}$ & $\begin{array}{l}0.82 \\
1.33\end{array}$ & $\begin{array}{l}0.20 \\
0.02\end{array}$ & $\begin{array}{l}0.18 \\
0.02\end{array}$ & $\begin{array}{l}0.15 \\
0.15\end{array}$ & $\begin{array}{l}0.20 \\
0.02\end{array}$ & $\begin{array}{l}0.12 \\
0.04\end{array}$ & $\begin{array}{l}0.04 \\
1.30\end{array}$ \\
\hline Total & 100.6 & 100.7 & 100.8 & 100.5 & 100.6 & 100.6 & 100.0 & 100.1 & 100.0 & 100.0 & 100.6 \\
\hline $\begin{array}{l}\mathrm{F}^{1 / 40} \\
\text { Total }\end{array}$ & $\begin{array}{c}0.62 \\
100.0\end{array}$ & $\begin{array}{c}0.69 \\
100.0\end{array}$ & $\begin{array}{c}0.78 \\
100.0\end{array}$ & $\begin{array}{c}0.53 \\
100.0\end{array}$ & $\begin{array}{r}0.56 \\
100.0\end{array}$ & $\begin{array}{c}0.01 \\
100.0\end{array}$ & $\begin{array}{r}0.00 \\
100.0\end{array}$ & $\begin{array}{r}0.06 \\
100.0\end{array}$ & $\begin{array}{r}0.00 \\
100.0\end{array}$ & $\begin{array}{r}0.02 \\
100.0\end{array}$ & $\begin{array}{r}0.55 \\
100.0\end{array}$ \\
\hline Li (ppm) & 4679 & 8324 & 15007 & 3512 & 2360 & 249 & nd & nd & 204 & nd & 6103 \\
\hline $\mathrm{Be}$ & 88 & 93 & 744 & 63 & 118 & 101 & nd & nd & 76 & nd & 1715 \\
\hline
\end{tabular}

1 See Tables 2 and 3 for experimental conditions and starting compositions.

Major element compositions by electron microprobe. Data normalized to $100 \%$. Lithium and Be concentrations by nuclear microprobe. Data are averages of several measurements.

excluded from the averages. Data in the two-stage experiment \#77 imply a $\mathrm{D}$ Be Biot/Mu value of 1 , inconsistent with the results for charges with higher bulk $\mathrm{Be}$ concentrations. These problems reflect the poor quality of our Be analyses at levels ,250 ppm and, in fact, our $\mathrm{D}$ Be values are constrained mainly from the Bedoped charges. In the latter (\#20, muscovite; \#49, biotite), glass Be concentrations (744-2295 ppm) reach the range appropriate for beryl saturation in silicic melts (Evensen et al. 1999). Indeed, beryl was found as a crystallizing phase when starting from the doped B2 and DK89 melts (Tables 2-3). D ${ }^{\text {Be }}$ values derived from the Be-doped charges are in good agreement with previous studies. The "trace Be concentration" data of Evensen \& London (2002) yield D ${ }^{\mathrm{Be}}$ Biot/L 1/4 0.45 (average of data below $7508 \mathrm{C}$ ) and $\mathrm{D}^{\mathrm{Be}} \mathrm{Mu} / \mathrm{L} 1 / 41.35$, slightly decreasing (to 0.30 and 0.87 , respectively) with increasing melt $\mathrm{Be}$ concentration. Taken as a whole, our data and those of Evensen \& London (2002) stress the preferential incorporation of $\mathrm{Be}$ in muscovite rather than in biotite during crystallization of silicic liquids.

\section{DiscUSSION}

Mica crystallization in moderately fractionated peraluminous granitic melts

In moderately fractionated (low $\mathrm{F}, \mathrm{Li}, \mathrm{Be}$ ) peraluminous granitic melts, one important conclusion that emerges from the experimental data is that mica crystallization is not strongly influenced by $\mathrm{f}_{2}$. Reduced experiments on DK89 leucogranite show that biotite crystallizes as the liquidus phase between $\sim 770$ and $8008 \mathrm{C}$ at 4000 bar (Scaillet et al. 1995). The new reduced DK89 experiment at $7208 \mathrm{C}$ is consistent with these results: biotite crystallizes spontaneously and biotite seeds remain stable and so the two methods, crystallization and dissolution, are mutually consistent (Table 8). In the same way, muscovite does not crystallize and muscovite seeds show evidence for breakdown to a biotite-bearing assemblage, confirming that, at $7208 \mathrm{C}$ under reducing conditions, biotite is the stable mica. Under oxidizing conditions, DK89 crystallizes biotite at 720 8C; biotite seeds are stable and muscovite seeds react to a biotite-bearing assemblage (Table 8). Therefore, biotite is also the stable mica in peraluminous granitic melts at $7208 \mathrm{C}$ under high $\mathrm{f}_{2}$. All biotites crystallized at $7208 \mathrm{C}$ have similar $\mathrm{Fe}^{3 \mathrm{p}} / \mathrm{RFe}$ (Table 5) and, more generally, similar chemistries irrespective of experimental $\mathrm{f}_{2}$ (Fig. 4), which indicates that compositions of aluminous biotites are not very sensitive to changes in redox conditions between $\mathrm{NNO}-1.5$ and NNO p3.

Under reducing conditions, Scaillet et al. (1995) found muscovite appearing at and below $6828 \mathrm{C}$, consistent with muscovite being unstable in the reduced $7208 \mathrm{C}$ charge of this study. Under oxidizing conditions, muscovite is also unstable at $7208 \mathrm{C}$ (Table 
TABLE 7. MICA-MELT PARTITION COEFFICIENTS

\begin{tabular}{|c|c|c|c|c|c|c|c|c|c|c|}
\hline \multirow{2}{*}{$\begin{array}{c}\text { Temperature (8C) } \\
\text { Charge \# }\end{array}$} & \multicolumn{6}{|c|}{620} & \multicolumn{4}{|c|}{720} \\
\hline & 4 & 17 & 20 & 77 & 77 & 39 & 27 & 46 & 49 & 49 \\
\hline \multicolumn{11}{|l|}{ muscovite } \\
\hline F (wt.\%) & 1.40 & 1.42 & 2.10 & 1.36 & - & - & - & - & - & - \\
\hline Li (ppm) & 809 & 983 & 3299 (885) & 555 & - & - & - & - & - & - \\
\hline $\mathrm{Be}(\mathrm{ppm})$ & 30 & 150 & $1180(245)$ & 104 & - & - & - & - & - & - \\
\hline \multicolumn{11}{|l|}{ biotite } \\
\hline F (wt.\%) & - & - & - & - & 2.17 & 2.72 & 0.08 & 0.06 & 3.00 & 2.94 \\
\hline Li (ppm) & - & - & - & - & 978 & 1508 & 223 & 204 & 4366 & 5500 \\
\hline $\mathrm{Be}(\mathrm{ppm})$ & - & - & - & - & 100 & 30 & 30 & 181 & 678 & 1294 \\
\hline \multicolumn{11}{|l|}{ glass } \\
\hline F (wt.\%) & 1.35 & 1.50 & 1.84 & 1.33 & 1.33 & 1.25 & 0.02 & 0.02 & 1.30 & 1.30 \\
\hline Li (ppm) & 4679 & 8324 & 15007 & 2360 (1740) & $2360(1740)$ & 3512 & 249 & 204 & 6103 & 8327 \\
\hline $\mathrm{Be}(\mathrm{ppm})$ & 88 & 93 & 744 & 118 (77) & $118(77)$ & 63 & 101 & 76 & 1715 & 2295 \\
\hline$D^{F_{M} / L}$ & 1.04 & 0.95 & 1.14 & 0.94 & 1.56 & 2.18 & 4.00 & 3.00 & 2.31 & 2.26 \\
\hline$D^{\mathrm{Li}} \mathrm{M} / \mathrm{L}$ & 0.17 & 0.12 & 0.22 & 0.24 & 0.41 & 0.43 & 0.90 & 1.00 & 0.72 & 0.66 \\
\hline$D^{B e} M / L$ & 0.34 & 1.61 & 1.59 & 0.85 & 0.88 & 0.48 & 0.30 & 2.38 & 0.40 & 0.56 \\
\hline
\end{tabular}

Data from Tables 4-6.

8), but appears stable at $7008 \mathrm{C}$ (Table 3). Therefore, comparison with experiments under reducing conditions (Scaillet et al. 1995) shows that increasing $\mathrm{f} \mathrm{O}_{2}$ slightly extends muscovite stability towards higher temperatures (700 versus $6808 \mathrm{C}$ ). We conclude that $\mathrm{f}$ $\mathrm{O}_{2}$ has a limited influence on muscovite stability in moderately fractionated peraluminous liquids.

Another important point to be emphasized is the control exerted by temperature on mica crystallization. In peraluminous leucogranitic melts, biotite crystallizes from high temperatures ( 800 8C, Scaillet et al. $1995)$ and is stable in most of the crystallization interval (between $\sim 800$ and $\sim 700$ 8C). Muscovite appearance is restricted to temperatures below $\sim 700$ 8C. Therefore, upon progressive cooling of leucogranitic melts at upper to middle crustal pressures $(, 400$ $\mathrm{MPa}$ ), biotite would be the first mica to crystallize, followed by muscovite. A biotite-muscovite (twomica) assemblage was found crystallizing in DK89 experiments both at low (Scaillet et al. 1995) and high (this study) $\mathrm{f} \mathrm{O}_{2}$ (Table 8 ). For reducing conditions, two-mica assemblages are known to persist stably until near the solidus (Scaillet et al. 1995). However, for oxidizing conditions, the stability of a two-mica assemblage near the solidus remains to be experimentally tested.

Mica crystallization in highly fractionated peraluminous pegmatitic liquids

Mica crystallization differs in fundamental aspects between highly fractionated (pegmatitic, B2) and moderately fractionated (granitic, DK89) liquids, the main difference being the very strong influence of $f$ $\mathrm{O}_{2}$ on pegmatitic liquids. Stable mica phaseassemblages in the B2 charges markedly depend on redox conditions. In the reducing experiments, biotite crystallizes spontaneously (this is also true in the reduced part of the two-stage experiment) and biotite seeds are stable. Muscovite does not appear, which suggests that it is unstable despite muscovite seeds showing no clear textural indication for reaction (Table 8). In comparison, in the oxidizing experiments, muscovite replaces biotite as the spontaneously crystallizing mica. Muscovite mantles biotite in the oxidized part of the two-stage experiment, and muscovite seeds appear stable. Biotite does not crystallize, and biotite seeds react to a phase assemblage which includes a phengitic mica (Table 8). Therefore, mica crystallization in F-, Li-, P-rich pegmatitic melts such as B2 is very sensitive to variations in redox state.

The contrasting role of $\mathrm{f}_{2}$ on mica crystallization in DK89 and B2 is clearly related to compositional changes which translate into different melt structures between the two samples. As a felsic granitic composition, DK89 has an aluminosilicate melt structure modified by the presence of $\mathrm{H}_{2} \mathrm{O}$ (Pichavant et al. 1992). In comparison, $B 2$ melts contain elevated concentrations of $\mathrm{F}, \mathrm{Li}$, and $\mathrm{P}$, in addition to $\mathrm{H}_{2} \mathrm{O}$. These components strongly modify the aluminosilicate melt structure (Pichavant et al. 1987b). This is evidenced by the solidus temperatures (550-600 8C) of B2, which are much lower than those 

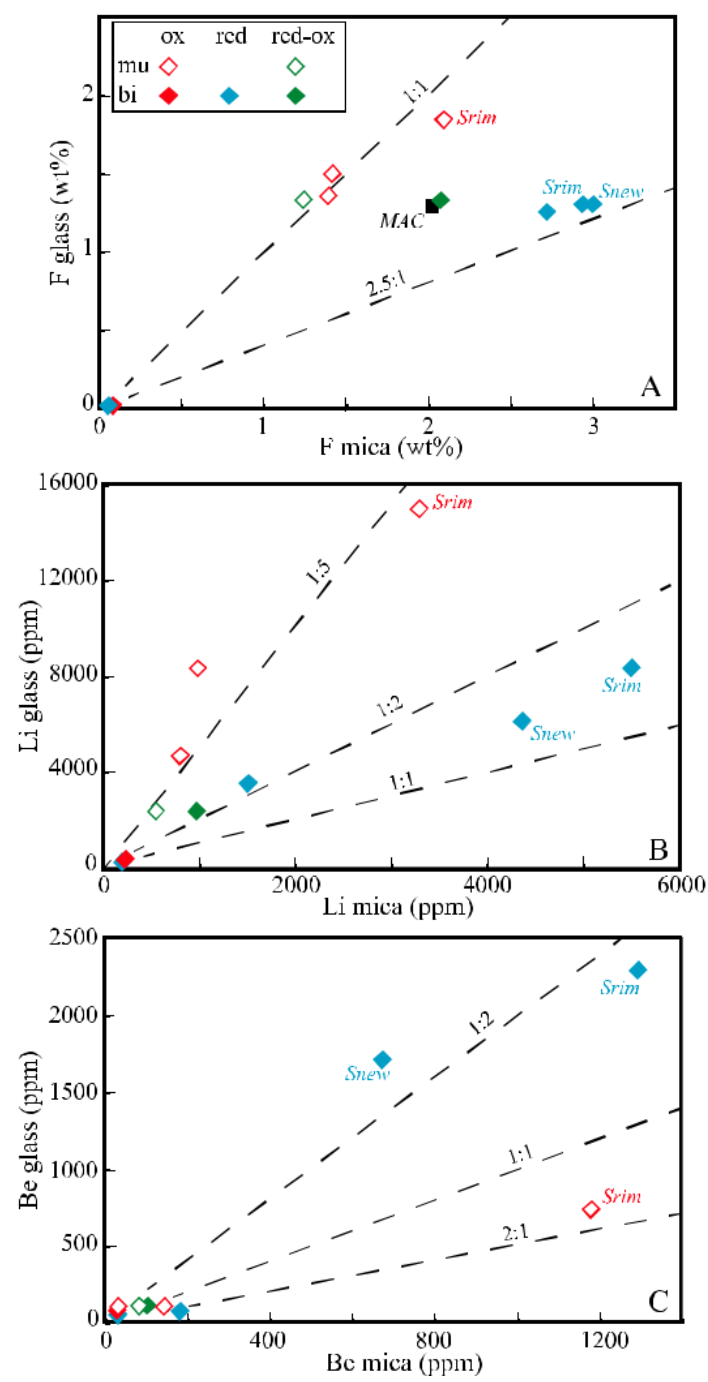

FiG. 5. F (A), Li (B), and Be (C) partitioning between mica and melt. Experimental data from Table 7. No difference is made between results from B2 and DK89. Red, blue, and green symbols refer to oxidized, reduced, and twostage (reduced-oxidized) experiments, respectively. Open symbols are for muscovite and filled symbols are for biotite solid solutions. The data points plotted are for $\mathrm{C}$ textural types except when specified (Srim: rim composition of either a muscovite or a biotite seed; Snew: newly grown crystals around biotite seeds, see text). In A, MAC: data for biotite microphenocrysts in the Macusani obsidian glass (Pichavant et al. 1988).

of felsic granitic melts (650-700 8C, Pichavant et al. 1987a). The strong influence of $\mathrm{f} \mathrm{O}_{2}$ on mica crystallization is another consequence of the highly specific structure of the B2 melt. This interpretation, which attributes to $\mathrm{F}, \mathrm{Li}$, and $\mathrm{P}$ a strong influence on phase equilibria, is consistent with our experimental results with the $\mathrm{F}-, \mathrm{Li}-$, and $\mathrm{Be}$-enriched $\mathrm{B} 2$ glass. At the temperature known to produce mica in the $\mathrm{B} 2$ experiments (620 8C), no mica was obtained when starting from the enriched glass (Table 2); this underlines the strong influence of melt $\mathrm{F}, \mathrm{Li}$, and $\mathrm{Be}$ concentrations on mica crystallization.

Experiments from this study demonstrate (somewhat paradoxically) that a stability field exists for biotite in chemically evolved pegmatitic melts poor in biotite-forming components such as $\mathrm{Fe}, \mathrm{Mg}$, and $\mathrm{Ti}$. Under reducing conditions, biotite is the sole mica stable in B2. It is also stable in DK89, occurring either alone or together with muscovite. The important point is that mica phase assemblages crystallizing at DNNO $\sim-1.5$ are biotite-bearing, irrespective of the degree of differentiation of the melt. For B2, the relationship between biotite crystallization and reducing $\mathrm{f}_{2}$ is a necessary condition since, under oxidizing $\mathrm{f}_{2}$, the stable mica is muscovite. Therefore, biotite crystallization in $\mathrm{B} 2$ melts indicates reducing $\mathrm{f}_{2}$. In contrast, for the DK89 melts, the relationship is only a sufficient condition, as biotite crystallization is possible in a range of $\mathrm{f}_{2}$ (see the preceding section).

Another point to emphasize concerns the oxidized mica phase assemblage stable in B2. Although a very simple one (muscovite alone), this assemblage is highly specific. The oxidized B2 experiments are the only ones from this study where muscovite crystallizes as the sole mica (see also Scaillet et al. 1995 and

Lukkari \& Holtz 2007). For B2, the relationship between muscovite crystallization and oxidizing $\mathrm{f}_{2}$ is a necessary condition (since under reducing $\mathrm{f}_{2}$ the stable mica is biotite), and this makes muscovite an indicator of oxidizing $\mathrm{f} \mathrm{O}_{2}$ in $\mathrm{B} 2$ melts. In comparison, for DK89, T-f $\mathrm{O}_{2}$ conditions for muscovite alone to be stable have not been delineated, and two-mica assemblages appear unspecific of redox conditions (see the preceding section). Experimental results for $\mathrm{B} 2$ and, in particular, the demonstration of necessary conditions between, respectively, biotite and musco-vite crystallization and reducing and oxidizing condi-tions offer interesting perspectives to constrain natural redox states in pegmatites on the basis of their mica phase-assemblages.

Comparison with micas in leucogranites and pegmatites

Our experimental results emphasize the influence of three main parameters, $\mathrm{f}_{2}, \mathrm{~T}$, and melt composition, in controlling mica crystallization. They open perspectives to constraining some critical variables, such as $\mathrm{f}_{2}$, during crystallization of evolved crustal 
TABLE 8. SUMMARY OF EXPERIMENTAL DATA ON MICA STABILITY

\begin{tabular}{|c|c|c|c|c|c|c|c|}
\hline \multirow[b]{3}{*}{ Method } & \multicolumn{3}{|c|}{ DK89 } & \multicolumn{4}{|c|}{ B2 } \\
\hline & \multicolumn{2}{|c|}{ Oxidizing ${ }^{1}$} & \multirow{2}{*}{$\frac{\text { Reducing }^{2}}{.7208 C^{*}}$} & \multicolumn{2}{|c|}{ Oxidizing ${ }^{1}$} & \multicolumn{2}{|c|}{ Reducing $^{2}$} \\
\hline & $7008 C$ & $7208 C$ & & $6208 C$ & $700-7508 C$ & $6208 C$ & $700-7508 C$ \\
\hline $\begin{array}{l}\text { Mica crystallization } \\
\text { Mica dissolution }\end{array}$ & $\begin{array}{l}\mathrm{Mu} \\
\mathrm{Bt}\end{array}$ & $\begin{array}{l}\text { no } \mathrm{Mu} \\
\mathrm{Bt} \\
\text { Mu unstable } \\
\text { Bt stable }\end{array}$ & $\begin{array}{l}\text { no Mu } \\
\text { Bt } \\
\text { Mu unstable } \\
\text { Bt stable }\end{array}$ & $\begin{array}{l}\text { Mu } \\
\text { no Bt } \\
\text { Mu unstable } \\
\text { Bt unstable }\end{array}$ & $\begin{array}{l}\text { no } \mathrm{Mu} \\
\text { no } \mathrm{Bt}\end{array}$ & $\begin{array}{l}\text { no Mu } \\
\text { Bt } \\
\text { Mu stable? } \\
\text { Bt stable }\end{array}$ & $\begin{array}{l}\text { no } \mathrm{Mu} \\
\text { no } \mathrm{Bt}\end{array}$ \\
\hline
\end{tabular}

${ }^{1}$ DNNO $1 / 4$ p 1 to $p 3$.

2 DNNO $1 / 4-1.6$ to -1.4 .

* Crystallization and dissolution data at $7208 \mathrm{C}$ from this study and crystallization data above $7208 \mathrm{C}$ from Scaillet et al. (1995).

melts ranging from leucogranitic to pegmatitic. However, the applicability of our experimental results first needs to be checked. This is done below by comparing the experimental data with natural mica assemblages and compositions from a representative plutonic example, the St. Sylvestre Massif. This granitic complex of Variscan age, in the NW part of the Massif Central (France), comprises several leucogranites and six types of pegmatites ranging from relatively unfractionated to LCT (Deveaud et al. 2013, 2015). The leucogranites are mainly of two-mica type, but some contain only biotite and one (Sagnes) only muscovite. The same is true for the pegmatites except that, in the Chabannes pegmatite, lepidolite (and not muscovite) occurs as the sole mica. Therefore, the St. Sylvestre Massif exhibits in the same complex the same types of mica assemblages as encountered in the experiments: biotite (type B) as found in both the DK89 (reduced and oxidized .720 8C) and B2 (reduced 620 8C) experiments, biotite-muscovite (type $\mathrm{BM}$ ) as in the DK89 (reduced ,680 8C and oxidized ,700 8C) experiments, and muscovite (type M) as in the B2 (oxidized $6208 \mathrm{C}$ ) experiments.

Compositions of micas in leucogranites and pegmatites from the St. Sylvestre Massif overlap, yet compositional trends are less extensive in the former than in the latter (Figs. 6, 7). Lepidolite from the Chabannes pegmatite is compositionally distinct from all the other micas. The Fe-rich micas define a continuous evolution from Fe biotite, to siderophyllite, to protolithionite. The least-evolved compositions (biotites from $\mathrm{B}$ and $\mathrm{BM}$ assemblages in leucogranites and pegmatites) are well reproduced in the DK89 experiments, both reduced and oxidized. Moderately evolved compositions (siderophyllites) found mostly in pegmatites (BM assemblages) are well matched by micas from the reduced (and the two-stage) B2 experiments. The most evolved compositions (proto- lithionites from BM assemblages in pegmatites) have not been experimentally duplicated.

In comparison, natural Al-rich micas display a more limited evolutionary trend (Figs. 6, 7). Muscovites from $\mathrm{BM}$ assemblages (pegmatites and leucogranites) are reproduced by the DK89 (both oxidized and reduced) and the B2 (oxidized) charges. The experiments simulate the beginning of the natural trend ( $\mathrm{M}$ assemblage in the Sagnes leucogranite), but the most-evolved compositions (BM assemblages in pegmatites) are not reproduced. Micas obtained by reacting $\mathrm{Fe}$ biotite seeds in oxidized $\mathrm{B} 2$ melts have no natural counterparts.

We conclude that mica compositions typical of Variscan pegmatites and leucogranites are reproduced in our experiments, thus demonstrating that the approach is both realistic and applicable. Yet important natural compositions have not been obtained experimentally. This is true for protolithionites similar to those present in the St. Sylvestre pegmatites and also for zinnwaldite, although this mica is absent in the Massif. Experimental Al-rich micas also show a more limited extension than their natural equivalents, and lepidolite compositions have not been approached. One hypothesis is that the crystallization of those more Li-, F-rich micas would require parental melts more $\mathrm{F}$-and Li-rich than B2 (e.g., Thomas \& Webster 2000). However, although additional experiments would be needed to test this hypothesis, the wide gap between mica compositions crystallized in this study and the lepidolite field should be noted (Fig. 7), as it casts doubts on the possibility of directly crystallizing lepidolite from a pegmatitic melt, were it more Li-and F-rich than B2. Lepidolite has been interpreted as a replacement product of former less $\mathrm{Li}$ rich phengite under the influence of post-magmatic fluids (e.g., Charoy et al. 1995). 


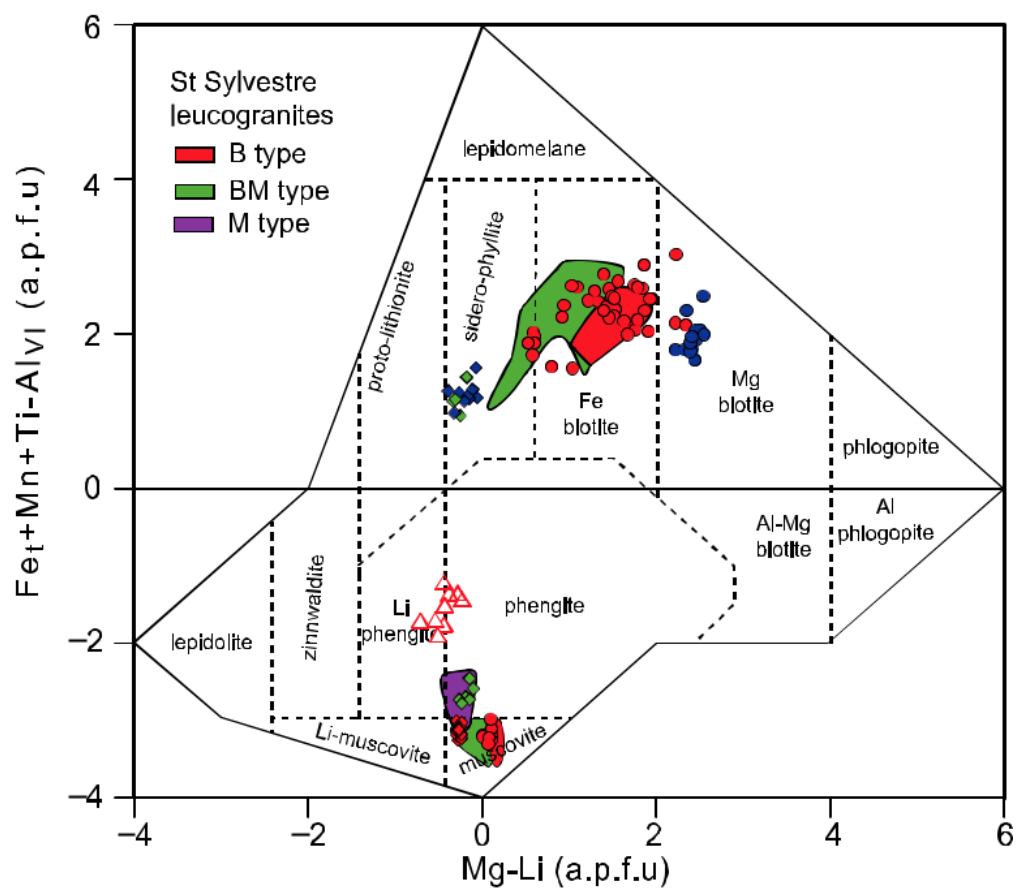

FIG. 6. Comparison between experimental micas from this study and natural micas from the St. Sylvestre leucogranites in the $\mathrm{Fe}_{\mathrm{t}} \mathrm{p} \mathrm{Mn} \mathrm{p} \mathrm{Ti}-\mathrm{Al}^{\mathrm{VI}}$ versus $\mathrm{Mg}$ - Li diagram of Tischendorf et al. (1997). Lithium contents of experimental and natural muscovites and biotites are estimated using equation [di 1] and [tri 1] respectively (Tischendorf et al. 1997). Experimental mica compositions are combined and the same coding (colors and symbols) as in Figures 2 (B2 data) and 4 (DK89 data) is used. For the natural micas, compositional domains are shown instead of individual analyses. They are distinguished from the mica phase assemblage. B type: biotite leucogranite (with subordinate muscovite); BM type: biotite-muscovite, i.e., two-mica, leucogranite; M type: muscovite leucogranite (Sagnes).

Redox evolution of leucogranites and pegmatites

Experimental results from this study demonstrate, first, that biotite-bearing mica assemblages (either B or BM type) crystallize under reducing conditions in peraluminous crustal melts ranging from moderately to highly fractionated (i.e., in leucogranitic to pegmatitic melts poor in $\mathrm{Fe}, \mathrm{Mg}$, and $\mathrm{Ti}$ ). Second, our experiments suggest that crystallization of muscovite as the sole mica (M-type assemblage) can be a potential indicator of oxidizing $\mathrm{f}_{2}$ in evolved silicic peraluminous melts. An M-type mica assemblage is commonly found in leucogranites (e.g., Scaillet et al. 1990, 1995, Nabelek et al. 1992) and pegmatites (e.g., Roda-Robles et al. 2012, Deveaud et al. 2013, 2015), crystallizing alone or together with other "AFM" phases such as tourmaline or garnet. Our data (in combination with those of Scaillet et al. 1995) show that an M-type assemblage cannot be produced as a result of progressive differentiation under constant and reducing $\mathrm{f}_{2}$ because a biotite-bearing assemblage would have to crystallize under such conditions.
Instead, results from B2 demonstrate a necessary condition between crystallization of an M-type assemblage and an oxidizing $\mathrm{f}_{2}$ (note that this necessary condition is still to be established for lessfractionated melts such as DK89). The consequences of this result are explored in detail below.

Based on the above, crystallization of an M-type assemblage from a fractionated pegmatitic melt implies, alternatively, a constant and oxidizing $\mathrm{f}_{2}$ or a change in redox conditions, from reducing to oxidizing, during crystallization. The former hypoth-esis is unlikely since the $\mathrm{f}_{2}$ of peraluminous felsic crustal melts such as as leucogranites and pegmatites is inferred to be reducing, ,FMQ (Pichavant et al. 1996). The latter hypothesis, discussed previously by Scaillet et al. (1995; Fig. 16), is taken up again and expanded below. It is generally accepted that, during progressive crystallization, cooling paths remain approximately parallel to $\mathrm{T}-\log \mathrm{O} \mathrm{O}_{2}$ oxygen buffers curves, illustrating a "self-buffering" of the redox state during magmatic evolution (Carmichael \& Ghiorso 1990). However, cooling paths crosscutting oxygen 


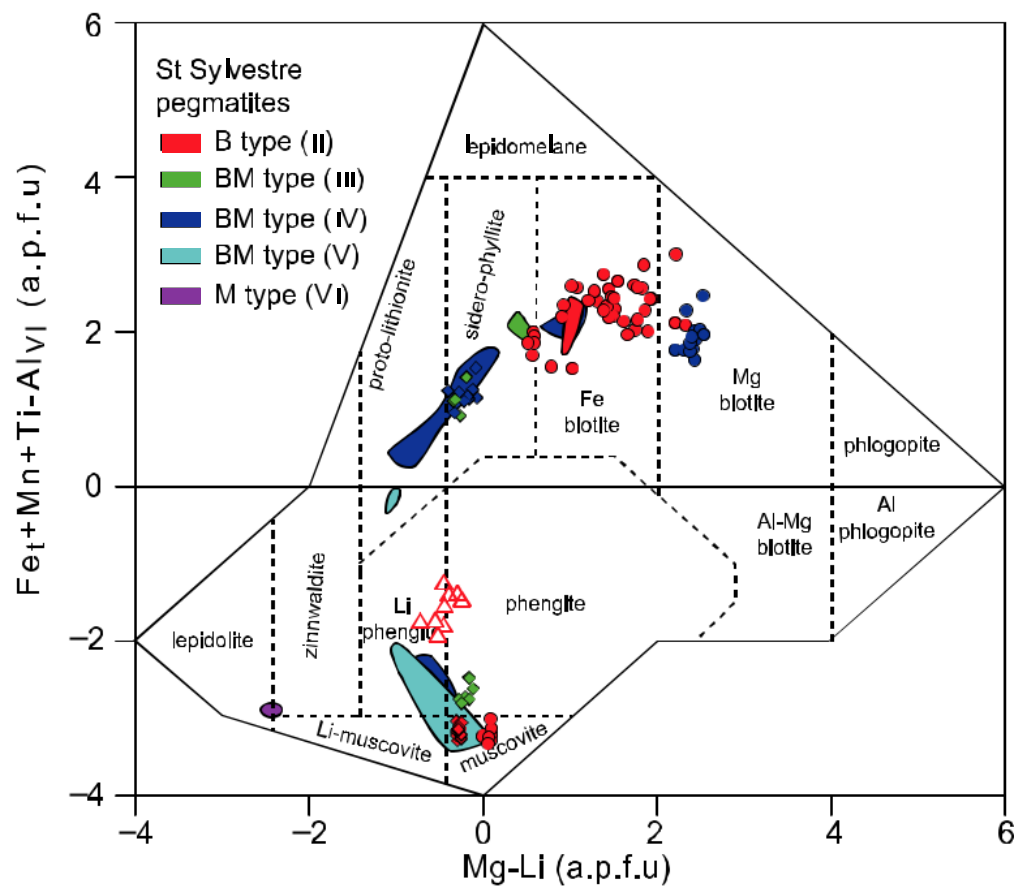

FIG. 7. Comparison between experimental micas from this study and natural micas from the St. Sylvestre pegmatites in the Fe p Mn p Ti - $\mathrm{Al}^{\mathrm{VI}}$ versus $\mathrm{Mg}$ - Li diagram of Tischendorf et al. (1997). Lithium contents of experimental and natural muscovites and biotites are estimated using equation [di 1] and [tri 1] respectively (Tischendorf et al. 1997). Experimental mica compositions are combined and the same coding (colors and symbols) as in Figures 2 (B2 data) and 4 (DK89 data) is used. For the natural micas, compositional domains are shown instead of individual analyses. They are distinguished from the mica phase assemblage and numbers referring to the class of pegmatite (from II to VI, Deveaud et al. 2013, 2015). B type: biotite pegmatite (with subordinate muscovite); BM type: biotite-muscovite, i.e., two-mica, pegmatite; M type: lepidolite pegmatite (Chabannes).

buffer curves at a high angle, and thus characterized by an "unbuffered" oxidizing evolution, have been documented in leucogranites (Scaillet et al. 1995) as well as in other granites (Czamanske \& Wones 1973). In the case of the Gangotri leucogranite, the oxidizing trend is revealed by the disappearance of biotite from the crystallization sequence and by a strong increase of whole-rock $\mathrm{Fe}_{2} \mathrm{O}_{3} / \mathrm{FeO}$ (Scaillet et al. 1995, Pichavant et al. 1996). Magmatic crystallization of cassiterite, as observed for example in the Beauvoir granite (Cuney et al. 1992) and in some pegmatites (Linnen et al. 1992, Visona \& Zantedeschi 1994, Deveaud et al. 2013, 2015), is another clear indication of oxidation since cassiterite solubility markedly decreases with increasing $\mathrm{f} \mathrm{O}_{2}$ (Linnen et al. 1995). In this paper, we have shown that crystallization of an Mtype mica assemblage in a pegmatitic melt constitutes further evidence for an oxidizing evolution.

Understanding the origin of such "unbuffered" oxidizing T- $\log \mathrm{O}_{2}$ trajectories is critical for model- ling the transport of metals in ore-bearing systems associated with crustal granitic magmatism because metal deposition dominantly takes place in the form of oxides (e.g., cassiterite, wolframite, niobiotanta-lates, others). Several processes have the potential to modify the $\mathrm{f} \mathrm{O}_{2}$ of cooling magmas. Open-system mechanisms such as assimilation of wall-rock materials can be important locally. In the same way, the influence of fluids of external origin (e.g., metamorphic, meteoric) needs to be examined. However, the discussion below is centered on processes having the potential to "self-oxidize" the granitic/pegmatitic body during its crystallization. In this context, it is worth emphasizing that leucogranitic or pegmatitic magmas contain dissolved volatiles (especially $\mathrm{H}_{2} \mathrm{O}$ and $\mathrm{F}$ ) at levels largely exceeding $\mathrm{Fe}$ concentrations (at. $\mathrm{H} / \mathrm{Fe}$ typically $\sim 40$; at. $\mathrm{F} / \mathrm{Fe}$ up to $\sim 10$ ). Therefore, in those systems, $\mathrm{f}_{2}$ is not expected to be buffered by the $\mathrm{FeO}-\mathrm{Fe}_{2} \mathrm{O}_{3}$ melt equilibrium. Previous work has shown that fractionation of $\mathrm{Fe}^{2 \mathrm{p}}$. 
bearing silicates is generally insufficient to explain deviations by several orders of magnitude from oxygen buffer curves (Carmichael 1991). The mechanism proposed below to explain the "self-oxidation" of leucogranitic and pegmatitic melts attributes a dominant influence to the main volatiles dissolved in the melt, $\mathrm{H}_{2} \mathrm{O}$ and $\mathrm{F}$. It can be written as:

$\begin{array}{cccccr}\mathrm{H}_{2} \mathrm{O} & \mathrm{p} & 2 \mathrm{~F}^{2} & 1 / 42 \mathrm{HFpO}^{2} & & 1 \\ \text { melt=gas } & \text { melt } & \text { gas } & \text { melt } & \text { ठ } \mathrm{P}\end{array}$

Dissociation of the $\mathrm{H}_{2} \mathrm{O}$ component of the melt under the influence of $\mathrm{F}$ produces $\mathrm{HF}$ as a gas component and increases the amount of $\mathrm{O}$ anions in the melt. With progressive separation of the vapor phase out of the crystallizing magma, reaction (1) would progressively shift toward the right. The net result would be a decrease of the cation/oxygen ratio of the melt (since $\mathrm{H}$ would be lost as $\mathrm{HF}$ ) and its oxidation according to:

$\begin{array}{rrrrrrr}\mathrm{FeO} \mathrm{p} & 0: 5 \mathrm{O}^{2} & \mathrm{p} & 0: 25 \mathrm{O}_{2} & 1 / 4 & \mathrm{FeO}_{2} & 2 \\ \text { melt } & \text { melt } & \text { gas } & \text { melt } & \text { ठ } \mathrm{P}\end{array}$

where $\mathrm{FeO}$ and $\mathrm{FeO}_{2}{ }^{-}$refer to the $2 p$ and $3 p$ iron-melt species respectively. Although a detailed parametrization of reaction (1) is to be reported elsewhere, it is worth emphasizing in the context of this paper that the evolution of F-Li contents in micas (see Figs. 6 and 7 for an example) actually demonstrate that $\mathrm{f} \mathrm{HF} / \mathrm{f} \mathrm{H}_{2} \mathrm{O}$ increases during the late stages of crystalliza-tion (e.g., Munoz 1987, Pichavant et al. 1988, Breiter et al. 1997) consistent with (1) being shifted to the right. Equation (1) is proposed as a viable mechanism to "self-oxidize" hydrous and F-bearing leucogranitic and pegmatitic magmas.

\section{Conclusions}

We have simulated experimentally the crystallization of micas in both moderately and highly evolved leucogranitic and pegmatitic melts. Special attention has been given to exploring the influence of $\mathrm{f}_{2}$ on mica assemblages and compositions. The results bring new perspectives for our understanding of the respective roles of melt composition, temperature, and redox conditions on mica crystallization in crustal magmas ranging from leucogranitic to pegmatitic. The main findings are as follows:

(1) For leucogranitic melts, mica crystallization is not strongly influenced by $\mathrm{f}_{2}$. Biotite is the liquidus phase, being later joined by muscovite, and a biotite-muscovite assemblage is stable down to near-solidus conditions under reducing $\mathrm{f}_{2}$. More data are needed to check the stability of biotitemuscovite near the solidus for oxidizing $\mathrm{f}_{2}$. Aluminous biotites have similar chemistries, indicating that their composition is not very sensitive to changes in redox conditions between $\mathrm{NNO}-1.5$ and NNO p3. Experimental biotites match the composition of natural biotites from leucogranites and pegmatites.

(2) For our F-, Li-, P-rich pegmatitic melt, mica crystallization is very sensitive to variations in redox state. The stable mica phase assemblage markedly depends on redox conditions. In the reducing experiments, biotite (siderophyllite composition) is the stable mica whereas, in the oxidizing experiments, biotite is replaced by muscovite (close to endmember composition). No biotite-muscovite assemblage was found

crystallizing from our pegmatitic melt. Biotite crystallization necessarily indicates reducing $\mathrm{f}_{2}$ and muscovite crystallization oxidizing $\mathrm{f}_{2}$. Biotite and muscovite compositions match the evolutionary trends for Fe-rich and $\mathrm{Al}$-rich micas in leucogranites and pegmatites. However, very Li-rich micas (protolithionite, zinnwaldite, lepidolite) were not found crystallizing in the experiments.

(3) Partition coefficients for $\mathrm{F}, \mathrm{Li}$, and Be stress the difference between biotite and muscovite fractionation. Fluorine and $\mathrm{Li}$ are preferentially incorporated in biotite rather than in muscovite and the opposite is true for Be. The F content of the melt is buffered by biotite and less so by muscovite fractionation. Both biotite and muscovite concentrate $\mathrm{Li}$ in silicic melts, the influence of muscovite being stronger than that of biotite. Biotite (but not muscovite) fractionation concentrates $\mathrm{Be}$ in the melt.

(4) Biotite-bearing mica assemblages (either B or BM type) crystallize under reducing conditions in peraluminous crustal melts. This applies regardless of the chemistry of the peraluminous crustal melt, from moderately fractionated (leucogranite) to highly fractionated (pegmatite poor in $\mathrm{Fe}, \mathrm{Mg}$, and $\mathrm{Ti}$ ).

(5) Crystallization of muscovite as the sole mica is a potential indicator of oxidizing $\mathrm{f}_{2}$. Such a mica assemblage, common in leucogranites and pegmatites, is diagnostic of an oxidizing evolution that deviates from classical buffered T-logf $\mathrm{O}_{2}$ trajectories. A mechanism based on the dissociation of $\mathrm{H}_{2} \mathrm{O}$ in the melt is proposed to account for the "self-oxidation" of hydrous and F-bearing leucogranitic and pegmatitic magmas. Such an oxidizing evolution might be of general importance during the crystallization of volatile-rich Fepoor crustal silicic melts and for the transport of metals in granite-related mineral deposits. 


\section{ACKNOWLEDGMENTS}

This paper is based on the Ph.D. thesis of ML, which was co-supervised by Jean-Louis Robert and supported in part by the BRGM. The Ph.D. thesis of SD is supported by the BRGM and the Region' Centre. We thank R. Linnen and D. London for reviews. This is a contribution from WP2 (Fluides Profonds) of Labex Voltaire (ANR-10-LABX-100-01 VOL-TAIRE).

\section{REFERENCES}

Abdel-Rahman, A.-F.M. (1994) Nature of biotites from alkaline, calc-alkaline, and peraluminous magmas. Journal of Petrology 35, 525-541.

B $_{\text {OUKILI }}$, B., H $\mathrm{H}_{\text {OLTZ }}$, F., B ENY $^{\text {, J.-M., \& R }}$ OBERT $\mathrm{Fe}-\mathrm{F}$ and Al-F avoidance rule in ferrous-aluminous $(\mathrm{OH}, \mathrm{F})$ biotites. Schweizerische Mineralogische und Petrographische Mitteilungen 82, 549-559.

Breiter, K., Fryda, J., Seltmann, R., \& Thomas, R. (1997) Mineralogical evidence for two magmatic stages in the evolution of an extremely fractionated P-rich rare-metal granite: the Podlesi Stock, Krusne Hory, Czech Republic. Journal of Petrology 38, 1723-1739.

Burnham, C.W., Holloway, J.R., \& Davis, N.F. (1969) Thermodynamic properties of water to $10008 \mathrm{C}$ and 10000 bars. Geological Society of America Special Paper 132.

CARmichael, I.S.E. (1991) The redox states of basic and silicic magmas: a reflection of their source regions? Contributions to Mineralogy and Petrology 106, 129141 .

Carmichael, I.S.E. \& Ghiorso, M. (1990) The effect of oxygen fugacity on the redox state of natural liquids and their crystallizing phases. In Modern Methods of Igneous Petrology: Understanding Magmatic Processes. Reviews in Mineralogy 24, 191-212.

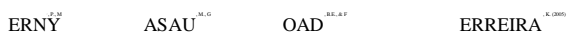

The Greer Lake leucogranite, Manitoba, and the origin of lepidolite-subtype granitic pegmatites. Lithos 80, 305321.

Charoy, B., Chaussidon, M., \& Noronha, F. (1995) Lithium zonation in white micas from the Argemela microgranite (central Portugal): an in situ ion-, electron-micrprobe, and spectroscopic investigation. European Journal of Mineralogy 7, 335-352.

Chou, I.-M. (1987) Oxygen buffer and hydrogen sensor techniques at elevated pressures and temperatures. In Hydrothermal Experimental Techniques. John Wiley \& Sons, Toronto, Ontario, Canada (61-99).

Clemens, J.D. \& Wall, V.J. (1981) Origin and crystallization of some peraluminous (S-type) granitic magmas. Canadian Mineralogist 19, 111-131.
Clemens, J.D., Holloway, J.R., \& White, A.J.R. (1986) Origin of an A-type granite: experimental constraints. American Mineralogist 71, 317-324.

Congdon, R.D. \& NASH, W.P. (1991) Eruptive pegmatite magma: rhyolite of the Honeycomb Hills, Utah. American Mineralogist 76, 1261-1278.

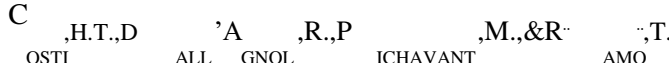

(2009) The peralkaline tin-mineralized Madeira cryolite albite-rich granite of Pitinga, Amazonian craton, Brazil: petrography, mineralogy and crystallization processes. Canadian Mineralogist 47, 1301-1327.

Cuney, M., Marignac, C., \& Weisbrod, A. (1992) The Beauvoir topaz-lepidolite albite granite (Massif Central, France): the disseminated magmatic Sn-Li-Ta-Nb-Be mineralization. Economic Geology 87, 1766-1794.

Czamanske, G.K. \& Wones, D.R. (1973) Oxidation during magmatic differentiation, Finmarka Complex, Oslo area, Norway. Part 2, the mafic silicates. Journal of Petrology 14, 349-380.

Dall'Agnol, R., Scaillet, B., \& Pichavant, M. (1999) An experimental study of a Lower Proterozoic A-type granite from the Eastern Amazonian craton, Brazil. Journal of Petrology 40, 1673-1698.

Deveaud, S., Gumiaux, C., Gloaguen, E., \& Branquet, Y. (2013) Spatial statistical analysis applied to rare-element LCT-type pegmatite fields: an original approach to constrain faults-pegmatites-granites relationships. Journal of Geosciences 58, 163-182.

Deveaud, S., Millot, R., \& Villaros, A. (2015) Lithium isotopes in micas: an efficient tool for granitic pegmatites classification? Chemical Geology 411,97-111.

Dodge, F.C.W., Smith, V.C., \& MAys, R.E. (1969) Biotites from granitic rocks of the central Sierra Nevada batholith, California. Journal of Petrology 10, 250-271.

Eugster, H.P. (1957) Heterogeneous reactions involving oxidation and reduction at high pressures and temperatures. Journal of Chemical Physics 26, 1760-1761.

Evensen, J.M. \& London, D. (2002) Experimental silicate mineral/melt partition coefficients for beryllium and the crustal Be cycle from migmatite to pegmatite. Geochimica et Cosmochimica Acta 66, 2239-2265.

Evensen, J.M., London, D., \& Wendlandt, R.F. (1999) Solubility and stability of beryl in granitic melts. American Mineralogist 84, 733-745

Hofstra, A.H., Todorov, T.I., Mercer, C.N., Adams, D.T., \& Marsh, E.E. (2013) Silicate melt inclusion evidence for extreme pre-eruptive enrichment and post-eruptive depletion of lithium in silicic volcanic rocks of the Western United States: implications for the origin of lithium-rich brines. Economic Geology 108, 1691-1701.

Huang, W.L. \& Wyllie, P.J. (1973) Melting relations of muscovite granite to $35 \mathrm{kbar}$ as a model for fusion of 
metamorphosed subducted oceanic sediments. Contributions to Mineralogy and Petrology 42, 1-14.

Huang, W.L. \& Wyllie, P.J. (1981) Phase relations of S-type granite with $\mathrm{H}_{2} \mathrm{O}$ to $35 \mathrm{kbar}$ : muscovite granite from Harney Peak, South Dakota. Journal of Geophysical Research 86, 10515-10529.

ICENHOWER, J. \& LONDON, D. (1995) An experimental study of element partitioning among biotite, muscovite and coexisting peraluminous silicic melt at $200 \mathrm{MPa}\left(\mathrm{H}_{2} \mathrm{O}\right)$. American Mineralogist 80, 1229-1251.

ICENHOWER, J.P. \& London, D. (1997) Partitioning of fluorine and chlorine between biotite and granitic melt: experimental calibration at $200 \mathrm{MPa} \mathrm{H} 2 \mathrm{O}$. Contributions to Mineralogy and Petrology 127, 17-29.

Johannes, W. \& Holtz, F. (1996) Petrogenesis and experimental petrology of granitic rocks. SpringerVerlag, Berlin, Germany.

Khodja, H., Berthoumieux, E., Daudin, L., \& Gallien, J.-P. (2001) The Pierre Suue laboratory nuclear microprobe as a multi-disciplinary analysis tool. Nuclear Instruments and Methods in Physics Research B 181, 83-86.

LAHLAFI, M. (1997) Role^ des micas dans la concentration des elements legers' $(\mathrm{Li}, \mathrm{Be}$ et $\mathrm{F})$ dans les granites crustaux: etude' experimentale' et cristallochimique. These' de Doctorat, Universite' d'Orleans,' France.

Leroy, J. \& Cathelineau, M. (1982) Les mineraux' phylliteux dans les gisements hydrothermaux d'uranium. I. Cristallochimie des micas herites" et neoformes." Bulletin de Mineralogie' 105, 99-109.

Linnen, R.L., Williams-Jones, A.E., \& Martin, R.F. (1992) Evidence for magmatic cassiterite mineralization at the Nong Sua aplite-pegmatite complex, Thailand. Canadian Mineralogist 30, 739-761.

Linnen, R.L., Pichavant, M., Holtz, F., \& Burgess, S. (1995) The effect of $\mathrm{f} \mathrm{O}_{2}$ on the solubility, diffusion and speciation of tin in haplogranitic melt at $8508 \mathrm{C}$ and 2 kbar. Geochimica et Cosmochimica Acta 59, 1579- 1588.

London, D., Morgan, G.B., VI, \& Hervig, R.L. (1989) Vapor-undersaturated experiments with Macusani glass $p$ $\mathrm{H}_{2} \mathrm{O}$ at $200 \mathrm{MPa}$, and the internal differentiation of granitic pegmatites. Contributions to Mineralogy and Petrology 102, 1-17.

Lukkari, S. \& Holtz, F. (2007) Phase relations of a Fenriched peraluminous granite: an experimental study of the Kymi topaz granite stock, southern Finland. Contributions to Mineralogy and Petrology 153, 273-288.

MaAløe, S. \& Wyllie, P.J. (1975) Water content of a granite magma deduced from the sequence of crystallization determined experimentally with water-undersaturated conditions. Contributions to Mineralogy and Petrology $52,175-191$.
Miller, C.F., Stoddard, E.F., Bradfish, L.J., \& Dollase, W.A. (1981) Composition of plutonic muscovite: genetic implication. Canadian Mineralogist 19, 25-34.

Monier, G. \& Robert, J.-L. (1986). Evolution of the miscibility gap between muscovite and biotite solid solutions with increasing lithium content: an experimental study in the system $\mathrm{K}_{2} \mathrm{O}-\mathrm{Li}_{2} \mathrm{O}-\mathrm{MgO}-\mathrm{FeO}-\mathrm{Al}_{2} \mathrm{O}_{3}-\mathrm{SiO}_{2}-\mathrm{H}_{2} \mathrm{O}-\mathrm{HF}$ at 600 8C, 2 kbar $\mathrm{P}_{\mathrm{H} 2 \mathrm{O}}$ : comparison with natural lithium micas. Mineralogical Magazine 50, 641-651.

M ,G.,M -D ,J.,\&L ONIER ERGOIL ANIEL ABERNARDIERE ,H.(1984)

Successive generations of muscovites and K-feldspars in the leucogranites of the Massif of Millevaches (French Massif Central). Bulletin de Mineralogie' 107, 55-68.

Munoz, J.L. (1987) F-OH and Cl-OH exchange in micas with applications to hydrothermal ore deposits. In Micas. Reviews in Mineralogy 13, 469-493.

Nabelek, P., Russ-Nabelek, C., \& Denison, J.R. (1992) The generation and crystallization conditions of the Proterozoic Harney Peak leucogranite, Black Hills, South Dakota, USA: petrologic and geochemical constraints. Contributions to Mineralogy and Petrology 110, 173191.

Nachit, H., Razafimahefa, N., Stussi, J.M., \& Carron, J.P. (1985) Composition chimique des biotites et typologie magmatique des granito“1des. Comptes Rendus Hebdomadaires de I'Academie des Sciences 301, 813-818.

NAney, M.F. (1983) Phase equilibria of rock-forming ferromagnesian silicates in granitic systems. American Journal of Science 283, 993-1033.

NeIva, A.M.R. (1976) The geochemistry of biotites from granites of northern Portugal with special reference to their tin content. Mineralogical Magazine 40, 453-466.

NeIVA, A.M.R. (2013) Micas, feldspars and columbitetantalite minerals from the zoned granitic lepidolitesubtype pegmatite at Namivo, Alto Ligonha, Mozambique. European Journal of Mineralogy 25, 967-985.

Pichavant, M. (1987) Effects of $\mathrm{B}$ and $\mathrm{H}_{2} \mathrm{O}$ on liquidus phase relations in the haplogranite system at 1 kbar. American Mineralogist 72, 1056-1070.

$\mathrm{P}$

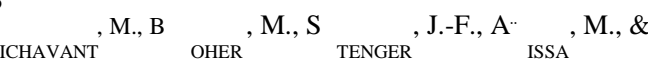
Charoy, B. (1987a) Relations de phases des granites de Beauvoir entre 1 et $3 \mathrm{kbar}$ en conditions de saturation en $\mathrm{H}_{2} \mathrm{O}$. Geologie' de la France 2-3, 77-86.

Pichavant, M., Valencia Herrera, J., Boulmier, S., Briqueu, L., Joron, J.-L., Juteau, M., Michard, A., Sheppard, S.M.F., Treuil, M., \& Vernet, M. (1987b) The Macusani glasses, SE Peru: evidence of chemical fractionation in peraluminous magmas. In Magmatic Processes: Physicochemical Principles. The Geochemical Society, Special Publication No. 1, University Park, Pennsylvania, United States (359-373).

Pichavant, M., Kontak, D.J., Herrera, J.V., \& Clark, A.H. (1988) The Miocene-Pliocene Macusani Volcanics, SE 
Peru I. Mineralogy and magmatic evolution of a two-mica aluminosilicate-bearing ignimbrite suite. Contributions to Mineralogy and Petrology 100, 300-324.

Pichavant, M., Holtz, F., \& McMillan, P.F. (1992) Phase relations and compositional dependence of $\mathrm{H}_{2} \mathrm{O}$ solubility in quartz-feldspar melts. Chemical Geology 96, 303319.

Pichavant, M., Hammouda, T., \& Scaillet, B. (1996) Control of redox state and $\mathrm{Sr}$ isotopic composition of granitic magmas: A critical evaluation of the role of source rocks. Transactions of the Royal Society of Edinburgh-Earth Sciences 87, 321-329.

Raimbault, L. (1998) Composition of complex lepidolitetype granitic pegmatites and of constituent columbitetantalite, Chedeville, Massif Central, France. Canadian Mineralogist 36, 563-583.

Raimbault, L. \& Azencott, C. (1987) Geochimie’ des el'ements' majeurs et traces du granite a 'metaux' rares de Beauvoir (sondage GPF, Echassieres)'. Geologie' de la France 2-3, 189-198.

Redhammer, G.J., Dachs, E., \& Amthauer, G. (1993) Mossbauer spectroscopic and X-ray powder diffraction studies of synthetic micas on the join annite $\mathrm{KFe}_{3} \mathrm{AlSi}_{3} \mathrm{O}_{10}(\mathrm{OH})(2)$-phlogopite $\mathrm{KMg}_{3} \mathrm{AlSi}_{3} \mathrm{O}_{10}(\mathrm{OH})(2)$. Physics and Chemistry of Minerals 22, 282-294.

Redhammer, G.J., Beran, A., Schneider, J., Amthauer, G., \& LotTermoser, W. (2000) Spectroscopic and structural properties of synthetic micas on the annite-siderophyllite binary: Synthesis, crystal structure refinement, Mossbauer, and infrared spectroscopy. American Mineralogist $85,449-465$.

Robie, R.A., Hemingway, B.S., \& Fisher, J.R. (1979) Thermodynamic Properties of Minerals and Related Substances at $298.15 \mathrm{~K}$ and 1 Bar $\left(10^{5}\right.$ Pascals $)$ Pressure and at Higher Temperatures. US Geological Survey Bulletin 1452.

Roda-Robles, E., Pesquera, A., Gil-Crespo, P., \& TorresRuIz, J. (2012) From granite to highly evolved pegmatite: a case study of the Pinilla de Fermoselle granitepegmatite system (Zamora, Spain). Lithos 153, 192-207.

Scaillet, B., France-Lanord, C., \& Le Fort, P. (1990) Badrinath-Gangotri plutons (Garhwal, India): petrological and geochemical evidence for fractionation processes in a high Himalayan leucogranite. Journal of Volcanology and Geothermal Research 44, 163-188.

Scaillet, B., Pichavant, M., Roux, J., Humbert, G., \& EFEVRE technique for measurement and control of $\mathrm{f}_{\mathrm{H} 2}$ at high temperatures and pressures. American Mineralogist 77, $647-655$.

Scaillet, B., Pichavant, M., \& Roux, J. (1995) Experimental crystallization of leucogranite magmas. Journal of Petrology 36, 663-705.

Schmidt, B., Scaillet, B., \& Holtz, F. (1995) Accurate control of $\mathrm{fH}(2)$ in cold-seal pressure vessels with the Shaw membrane technique. European Journal of Mineralogy 7, 893-903.

SPEer, J.A. \& Becker, S.W. (1992) Evolution of magmatic and subsolidus AFM mineral assemblages in granitoid rocks: Biotite, muscovite, and garnet in the Cuffytown Creek pluton, South Carolina. American Mineralogist 85, 449-465.

TAylor, J.R., Wall, V.J., \& Pownceby, M.I. (1992) The calibration and application of accurate redox sensors. American Mineralogist 77, 284-295.

Thomas, R. \& Webster, J.D. (2000) Strong tin enrichment in a pegmatite-forming melt. Mineralium Deposita 35, 570 582.

$\mathrm{T}$

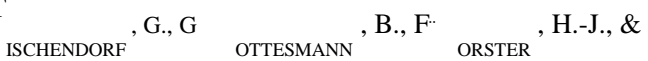

Trumbull, R.B. (1997) On Li-bearing micas: estimating Li from electron microprobe analyses and an improved diagram for graphical representation. Mineralogical Magazine 61, 809-834.

Veksler, I.V. \& Thomas, R. (2002) An experimental study of B-, P- and F-rich synthetic granite pegmatite at 0.1 and $0.2 \mathrm{GPa}$. Contributions to Mineralogy and Petrology 143 , 673-683.

Visona, D. \& Zantedeschi, C. (1994) Spodumene, petalite and cassiterite, new occurrence in Himalayan leucogranite pegmatites: petrological implications. $16^{\text {th }}$ IMA General Meeting, Pisa, Italy, 429 pp.

Webster, J.D., Holloway, J.R., \& Hervig, R.L. (1987) Phase equilibria of a $\mathrm{Be}, \mathrm{U}$, and F-enriched vitrophyre from Spor Mountain, Utah. Geochimica et Cosmochimica Acta 51, 389-402.

Weidner, J.R. \& Martin, R.F. (1987) Phase equilibria of a fluorine-rich leucogranite from the St. Austell pluton, Cornwall. Geochimica et Cosmochimica Acta 51, 15911597. 